\title{
El urbanismo vacceo
}

\author{
The Vaccean urbanism
}

\author{
José David Sacristán de Lama \\ Arqueólogo Territorial de la Junta de Castilla y León. \\ Servicio Territorial de Cultura de Valladolid. C/ San Lorenzo 5, 1º. 47001-Valladolid. \\ saclamjo@jcyl.es
}

Recibido: $15-12-2010$

Aceptado: 13-04-2011

\begin{abstract}
RESUMEN
La cuenca media del Duero conoció durante la Segunda Edad del Hierro un sistema de ocupación del espacio caracterizado por núcleos grandes y distantes entre sí, sin apenas aldeas dependientes, y con un urbanismo bien planificado. Se propone que este modelo se originó por concentración, estimulada y dirigida, de las aldeas del grupo Soto de Medinilla, a lo largo del siglo IV a.C., como resultado de un incremento de la producción, tal vez debido a la generalización de la reja de arado de hierro, lo que permitió el autoabastecimiento de las concentraciones urbanas aprovechando las amplias vegas y campiñas, que se ocuparon selectivamente. Esto sugiere que era un modelo de poblamiento de baja densidad poblacional, que no agotó la capacidad de carga del territorio. Se estudia la evolución del poblamiento, que permanecería estable hasta las guerras de Sertorio y Pompeyo al finalizar el primer cuarto del siglo I a.C., cuando desaparecieron la mitad de las ciudades. Las que sobrevivieron, constituyeron la base del entramado urbano de época romana.
\end{abstract}

Palabras Clave: Valle Medio del Duero. Segunda Edad del Hierro. Vacceos. Oppida. Fortificaciones.

\begin{abstract}
During the Second Iron Age, the occupation of space in the Duero central basin was characterized by large, well-planned settlements, distant from each other and with hardly any dependent small villages. It is suggested that this model was started throughout the $4^{\text {th }}$ century B.C. by the stimulated and directed concentration of the villages of the Soto de Medinilla culture, as the result of an increase in production, perhaps due to the widespread use of the iron ploughshare. This allowed for the self-sufficiency of the urban concentrations, using the fertile plains and farmlands which were occupied selectively. This indicates a low density settlement model which did not exhaust the carrying capacity of the territory. The paper analyzes the settlement evolution, which would remain stable until the wars of Sertorius and Pompey at the end of the first quarter of the $1^{\text {st }}$ century B.C., when half of the towns disappeared. Those that survived formed the basis of the urban framework of the Roman period.
\end{abstract}

KeY words: Middle Duero Valley. Second Iron Age. Vaccaei. Oppida. Fortifications.

Sumario: 1. El territorio. 2. La ocupación del territorio. 3. La ciudad y su entorno. 4. Economía. 5. Identidad étnica, organización política y sociedad. 6. Evolución del poblamiento. 7 Reflexiones finales. 
El espacio geográfico que abarca este trabajo ${ }^{1}$ se ciñe a las tierras sedimentarias del interior de la Meseta, no por motivos puramente geográficos, sino porque éste fue, casi milimétricamente, el marco en que se desarrolló durante la Edad del Hierro avanzada un peculiar modelo poblacional que se aparta netamente de los patrones habituales en otros ámbitos peninsulares, incluso vecinos. Los análisis efectuados (Sacristán 1996; Sacristán 1989; San Miguel 1993; Sacristán 1994; Sacristán et al. 1995) han revelado una imagen sorprendente, que se ha tardado tiempo en aceptar. Frente a la extrapolación mecánica de un estereotipo con base en las Fuentes clásicas, válido para describir la situación contemporánea en otras áreas peninsulares, con un esquema claramente piramidal, con escasos núcleos de carácter urbano y multitud de pequeños asentamientos dependientes de aquellos en varios niveles (ciudades, aldeas, torres), en el interior meseteño se configuró un sistema singular caracterizado por el predominio de grandes núcleos, la escasa jerarquización entre ellos y un desarrollado urbanismo. En estas páginas, espero aportar algunas claves para empezar a entender este peculiar modelo, como se ha demandado (Fernández-Posse 1998: 178).

\section{El territorio}

El interior de la Meseta es una extensa altiplanicie formada por espesos sedimentos depositados en un medio lacustre durante la época miocénica y delimitada por los sistemas montañosos Cantábrico, Ibérico y Central y la penillanura occidental. El conjunto está ligeramente basculado hacia el oeste, hacia donde corre el Duero, que lo drena junto con su red de afluentes. La red fluvial y otros factores de erosión han roto la original uniformidad del espacio, dando lugar a diversos ambientes:

- los páramos, restos más o menos extensos de la primitiva llanura sedimentaria, que tienen un especial desarrollo en el cuadrante nororiental, al este del Pisuerga, con frecuencia coronados por una capa caliza.

- los valles fluviales, que tajan los páramos dando lugar a una variada fenomenología ero- siva en sus bordes y cuestas, con barranqueras, lenguas salientes o espigones y cerros testigos. Los valles propiamente dichos, que pueden tener un mayor o menor desarrollo, en algunos tramos forman amplias vegas.

- las campiñas, o espacios en los que la erosión ha desmantelado las capas superiores del páramo, quedando expuestos depósitos aptos para el cultivo y formando, bien zonas de suave transición entre los páramos y los valles, o bien amplios territorios, como la Tierra de Campos, donde predomina un paisaje de ligeras ondulaciones. Al sur del Duero hay otra amplia campiña cubierta por un manto de arenas recientes.

Para delimitar este espacio en los mapas regionales, por el norte y por el este resulta especialmente expresiva la curva altimétrica de 1.000 metros, que marca la transición entre los páramos y el piedemonte de los sistemas Cantábrico e Ibérico. Por debajo de la línea de 800 metros quedan las principales vegas y las campiñas, y por encima los páramos. Por el sur del Duero, no veo obstáculos para llevar el límite del territorio de estudio hasta el Tormes, donde Salmantica todavía responde a las pautas globales del interior de la cuenca. Este borde meridional de las tierras sedimentarias no queda bien perfilado más hacia oriente por accidentes fácilmente reconocibles en los mapas, pero sigue más la línea de 800 metros que la de 1.000 , excepto en el extremo sudeste. Por el oeste pondremos el límite, en vez de en las formaciones sedimentarias, en el río Esla, que marca una clara brecha cultural y en el sistema de poblamiento.

Esta amplia área, de unos $32.000 \mathrm{~km}^{2}$, coincide bastante rigurosamente, como he dicho, con la extensión de un singular modelo de ocupación territorial. Es un marco, por otra parte, que se aproxima al de un estudio anterior (Sacristán et al. 1995), si bien allí, al ceñirse a unos límites regulares, se prescindía de algunos sectores de la periferia. Por ello, aquí se observarán algunas diferencias de detalle, que proporcionan una visión más ajustada del conjunto. Como veremos, este fue el país de los vacceos, que ocuparon la zona nuclear y de mayor extensión, y el de los turmogos, en la parte nororiental, pero, 
en los bordes de este espacio, también responden al mismo patrón de poblamiento las ciudades arévacas situadas al oeste del sistema ibérico, además de la Brigeco astur en el oeste y Salmantica (fuera vaccea o vettona) en el suroeste.

\section{La ocupación del territorio (Fig. 1)}

En este territorio de la cuenca sedimentaria, conocemos 63 núcleos de población de la Segunda Edad del Hierro, número que hay motivos para suponer que se corresponde razonablemente bien con el de los que realmente existieron y que debieron de ser en su práctica totalidad sincrónicos, al menos hasta que muchos de ellos desaparecieron a principios del siglo I a.C. como consecuencia de las guerras de Sertorio y Pompeyo ${ }^{2}$

El estudio de estos asentamientos en el territorio revela un modelo o patrón de poblamiento, operativo desde el siglo IV a.C. hasta la guerra sertoriana, que responde a una repetición singular tanto de las características de los propios núcleos de población como de sus pautas de emplazamiento y ocupación territorial, que describiré someramente. Más adelante analizaré su origen y evolución.

1.- De manera genérica, se trata de núcleos grandes y distantes.

"Grandes" y "distantes" son términos ciertamente relativos y deben entenderse en el contexto peninsular contemporáneo. En la mayor parte de los casos son comparables, tanto en extensión como en distancia mutua, a las ciudades que jerarquizan el hábitat en otras zonas peninsulares en esta etapa avanzada de la Edad del Hierro.

Son, en primer lugar, núcleos grandes. Aunque en bastantes casos no se ha medido o existen serias dificultades para medir la superficie urbana, se puede asegurar que, con pocas excepciones, ocupan entre 5 y 20 ha. En concreto, de los 47 núcleos de los que se pueden aportar datos aproximados (con alguna corrección sobre Sacristán et al. 1995), al menos 24 ocupan más de 10 ha (algunos de ellos, más de 20: Olmillos de Sasamón, Villavieja de Muñó, Valoria y Padilla de Duero, en torno a 25 ha; y
Tardajos y Montealegre de Campos superan las 40 ha. Sin embargo, son cuando menos dudosas las extensiones de más de 60 ha. que se han estimado para otros núcleos); 13 ocuparían entre 5 y 10 ha, y sólo 11 parecen medir menos de 5 ha (pero la mayoría de ellos en torno a 4 ha). De estos últimos, sólo dos (Tabanera y Valdecañas) son fundaciones nuevas y los demás son antiguos poblados soteños, casi todos en la Tierra de Campos, que excepcionalmente no fueron absorbidos, sino sólo incorporados al dominio de las nacientes ciudades, por su valor estratégico (como el del Cerro del Castillo de Tordehumos) o por otras razones. Nada que ver, en todo caso, con la norma de otras áreas, como insistiré al tratar sobre la jerarquización.

Son núcleos, también, distantes entre sí. Las distancias entre vecinos más próximos no son, en todo caso, regulares en todo el territorio, sino que varían entre unos $10 \mathrm{~km}$ de media en la Tierra de Campos y los casi $20 \mathrm{~km}$ en el amplio sector vacceo del este del Pisuerga. En la cuenca del Arlanzón, es decir, en el territorio turmogo, son notablemente uniformes, de unos $15 \mathrm{~km}$. Pero tan expresivas como las distancias entre vecinos más próximos pueden resultar las existentes entre vecinos a lo largo de vías naturales de comunicación, como se observa en las siguientes secuencias:

\section{- Eje Pisuerga-Arlanzón:}

Simancas - Soto de Medinilla, $14 \mathrm{~km}$

Soto de Medinilla - Valoria, $19 \mathrm{~km}$

Valoria - Tariego, $12 \mathrm{~km}$

Tariego- Palenzuela, $35 \mathrm{~km}$

Palenzuela - Villavieja de Muñó, 27 km.

- Duero:

Zamora - Villalazán, $12 \mathrm{~km}$

Villalazán - Toro, $18 \mathrm{~km}$

Toro - Tordesillas, $36 \mathrm{~km}$

Tordesillas - Simancas, $17 \mathrm{~km}$

Simancas - Padilla, $54 \mathrm{~km}$

Padilla - Roa, $22 \mathrm{~km}$

Roa - La Vid, 39 km.

Son igualmente reveladoras las distancias a lo largo del trayecto de lo que luego sería la vía autrigona, por cuanto se trata de un rosario de ciudades bien identificadas, conocidas por sus nombres antiguos, sin núcleos menores entre 
ellas y sin variación en la secuencia entre las etapas prerromana y romana:

Lacobriga (Carrión de los Condes) - Dessobriga (Melgar/Osorno), $23 \mathrm{~km}$

Dessobriga - Segisamon (Sasamón), 23 km

Segisamon - Deobrigula (Tardajos), 20 km

A pesar de lo que se podría pensar a la vista de estas distancias, el poblamiento no es disperso o uniforme en el conjunto del territorio, sino que deja amplias áreas vacías y se concentra en determinados espacios, siguiendo las pautas que se indican en los siguientes puntos.

\section{2.- Adaptación a la red fluvial principal.}

En el sector central de la cuenca, los núcleos de población se instalaron preferentemente junto a los principales corredores fluviales (9 junto al Duero; 15 en el sistema Pisuerga-ArlanzónCarrión, y 8 en el Esla-Cea, lo que suma el 50\% del total), con clara preferencia por los sectores con vegas más espaciosas. Resulta llamativa la aparente falta de interés por algunos valles que surcan el sector central de la cuenca, como el del Arlanza y el del Esgueva, que llegan a tener una cierta amplitud y en los que sólo encontramos algún asentamiento en las cabeceras. Como excepción, hay tres centros, Vertabillo, Tabanera y Valdecañas, situados en valles de cursos menores, pero, significativamente, en el punto en que los mismos se amplían para abrirse al gran pasillo del Pisuerga, del que son tributarios.

En los sectores periféricos del territorio, fuera de los corredores principales del centro de la cuenca, también se eligen emplazamientos junto a los valles de la red secundaria (Huérmeces, Ubierna, Odra, Duratón, etc.). Incluso en la Tierra de Campos, donde la aptitud agrícola no se limita a los valles, se prefiere el asentamiento junto a los pequeños cursos de agua locales.

\section{3.- Vacío de los páramos y llanuras arenosas.}

El interior de estos amplios espacios interfluviales se encuentra, sin excepción, vacío de asentamientos, lo que se explica fácilmente en el caso de los páramos por sus condiciones de extrema dureza y la limitación de su potencial económico (madera, caza y bellotas, que eran recursos complementarios).

En lo que se refiere a las extensas campiñas arenosas del sur del Duero, contrasta vivamente su recurrente aprovechamiento por grupos humanos durante toda la Prehistoria Reciente, en especial en torno a los abundantes humedales, con la desocupación que se produce durante la Edad del Hierro. Probablemente, este cambio se debió a la incapacidad para sustentar comunidades de una cierta amplitud, pese a la facilidad que ofrecían para los trabajos de roturación (lo que explicaría su interés anterior). En la práctica, las tierras situadas inmediatamente al sur del Duero fueron un desierto poblacional que separaba a Cauca y Nivaria del grueso de las otras urbes vacceas situadas más al norte, y que se extendía hacia occidente abarcando el interfluvio Duero-Tormes.

Estos desiertos interiores pueden interpretarse, pues, desde una perspectiva económica, pero no deben descartarse los motivos estratégicos para explicar, por ejemplo, el amplio vacío existente entre los vacceos orientales y los arévacos.

\section{4.- Apertura a la Tierra de Campos.}

La Tierra de Campos es una extensa campiña que presenta buenas condiciones para el aprovechamiento agrícola, preferentemente cerealista. Por ello, frente a los pasillos entre páramos que concentran el poblamiento en el resto de la cuenca, se observa una cierta tendencia a la dispersión de núcleos por el interior de este espacio, aunque con matices, por cuanto los principales asentamientos que se abren hacia la campiña y la explotan se instalaron en sus límites, en el borde del páramo de Torozos (Montealegre, Tiedra, Torrelobatón, Mota del Marqués), y los demás núcleos se acomodan a los irregulares cursos de agua comarcales, como el Sequillo (Medina de Rioseco, Tordehumos, Villagarcía de Campos) o el Valderaduey (Vi1lalpando, Molacillos).

\section{5.- Ausencia de intervisibilidad.}

Con algunas excepciones, en particular en la Tierra de Campos vallisoletana y palentina, éste es un rasgo general y llamativo, fruto de las distancias y de la sinuosidad de la línea de 


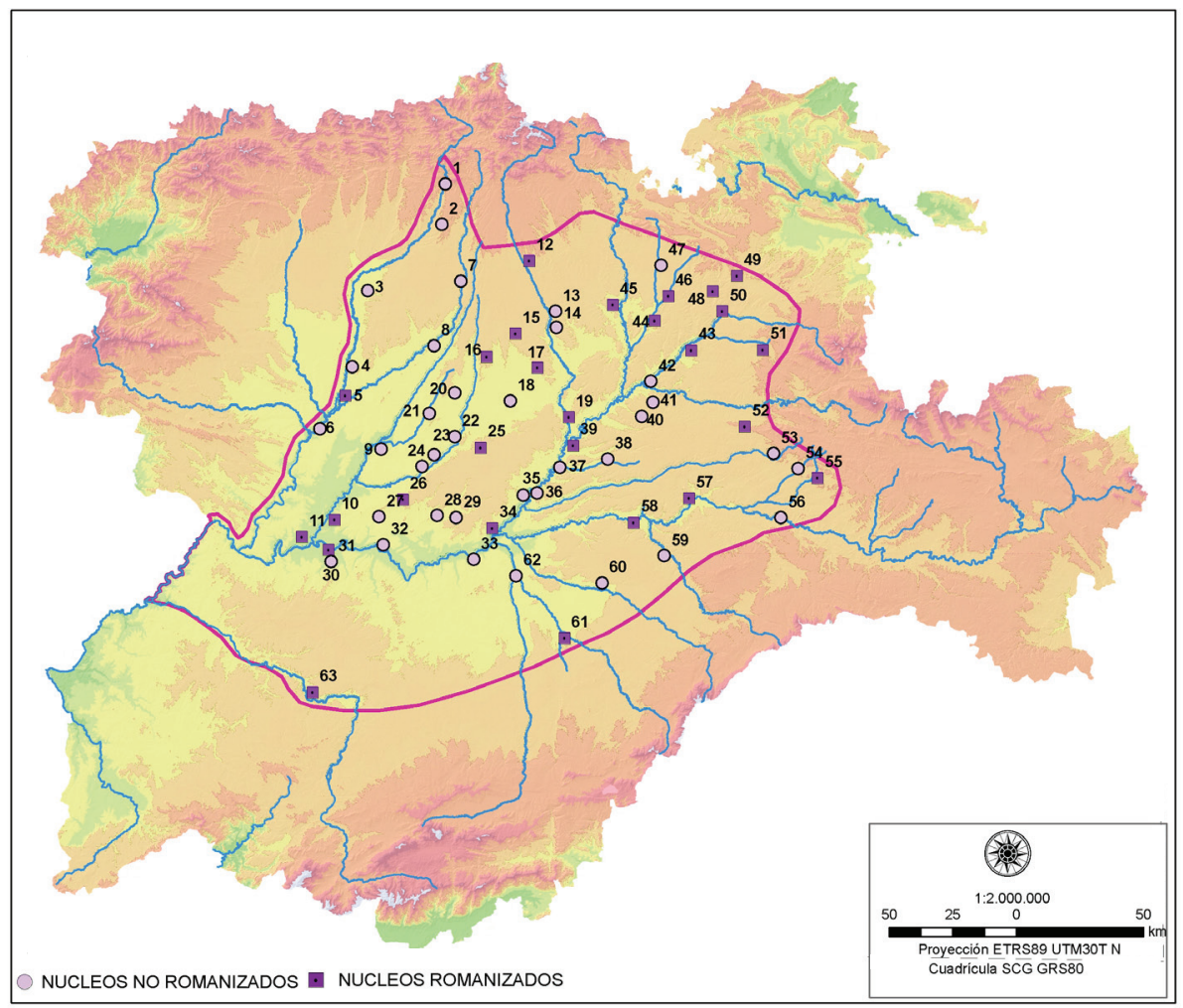

Figura 1.- Poblamiento de la cuenca sedimentaria del Duero durante la Segunda Edad del Hierro.1, Villapadierna; 2, San Cipriano de Rueda; 3, Corbillos de los Oteros; 4, Castrillino; 5, Fuentes de Ropel (Brigeco); 6, Barcial del Barco; 7, Villamol; 8, Melgar de Abajo; 9, Villalpando; 10, Molacillos; 11, Zamora; 12, Saldaña; 13, Población de Soto; 14, Carrión de los Condes (Lacobriga); 15, Calzadilla de la Cueza (Viminatio); 16, Cisneros; 17, Paredes de Nava; 18, Castromocho; 19, Palencia (Pallantia); 20, Cuenca de Campos; 21, Aguilar de Campos; 22, Medina de Rioseco; 23, Tordehumos; 24, Villagarcía de Campos; 25, Montealegre; 26, Tiedra; 27 , Abezames; 28, Mota del Marqués; 29, Torrelobatón; 30, Villalazán (Albocela/Arbucala); 31, Bamba; 32, Toro; 33, Tordesillas; 34, Simancas (Septimanca); 35, Valladolid (Pago de Gorrita); 36, Valladolid (Soto de Medini1la); 37, Valoria la Buena; 38, Vertabillo; 39, Tariego de Cerrato; 40, Valdecañas; 41, Tabanera; 42, Palenzuela (Pallantia); 43, Villavieja de Muñó; 44, Castrojeriz; 45, Osorno/Melgar de Fernamental (Dessobriga); 46, Olmillos de Sasamón (Segisamon preaugústea); 47, Villadiego; 48, La Nuez de Abajo; 49, Ubierna; 50, Tardajos (Deobrigula); 51, Los Ausines; 52, Solarana; 53, Pinilla Trasmonte, 54, Arauzo de Torre; 55, Quintanarraya/ Hinojar del Rey (Clunia prerromana); 56, La Vid; 57, Roa (Rauda); 58, Padilla de Duero (Pintia); 59, Torre de Peñafiel; 60, Cuéllar; 61, Coca (Cauca); 62, Matapozuelos; 63, Salamanca (Salmantica/Helmantica).

los páramos que bordean los valles, así como de la práctica inexistencia de núcleos de población dependientes, de lo que se tratará a continuación.

\section{6.- Escaso desarrollo de la jerarquización en- tre núcleos.}

De lo ya expuesto acerca de las dimensiones de los núcleos y de las distancias entre ellos se infiere una imagen de escasa jerarquización del poblamiento. Rasgo que de nuevo contrasta con el sistema nítidamente jerarquizado que, salvo en el norte y noroeste donde no llegó a cuajar el fenómeno urbano, se impuso de manera general en otros sectores peninsulares, incluidos los vecinos arévacos (Jimeno y Arlegui 1995; Jimeno 2000; Heras 2000) y vettones (Álvarez-Sanchís 1999), organizado como una pirámide con un estrecho vértice ocupado por los núcleos principales de carácter urbano y una amplia base formada por numerosos asentamientos satélites, menores y mucho más numerosos, en varios niveles, con diferencias regionales en cuanto al grado de complejidad. 
En contraste, y sin olvidar que la jerarquía no se reduce al tamaño, en la cuenca media del Duero los signos visibles de jerarquía aparecen, cuando menos, muy atemperados, resultando especialmente llamativa la ausencia casi total de los establecimientos de menor rango, que son precisamente los más abundantes en otros ámbitos, a lo que se suma la falta de intervisibilidad y el espléndido aislamiento de la mayoría de los núcleos. Además, aquí los casos de dependencia se reducen a algunos poblados de cierta entidad que sobrevivieron a la etapa de sinecismo que tuvo lugar durante el siglo IV a.C., cuando, como veremos, nacieron las ciudades, mientras en otras áreas la jerarquización se produjo por fundación más tardía de múltiples aldeas y caseríos, en su mayor parte muy pequeños.

El escaso desarrollo de la jerarquía se desprende también de la vecindad entre núcleos de clara entidad urbana citados en las Fuentes, sin que entre ellos hubiera otras poblaciones intermedias. Es el caso de Septimanca, Pintia y Rauda en el Duero, o el ya citado de Lacobriga, Dessobriga, Segisamon y Deobrigula en la línea que en época romana siguió la vía autrigona.

Resulta igualmente ilustrativo el panorama que transmiten las Fuentes para la etapa romana altoimperial (en época republicana sólo se mencionan expresamente Arbucala, Pallantia, Intercatia, Cauca y Clunia), cuando habían desaparecido la mitad de las poblaciones existentes hasta la guerra sertoriana. En ese momento altoimperial, llama la atención la gran concordancia entre los 28 núcleos urbanos romanos con antecedente indígena conocidos por la arqueología (que fueron los que sobrevivieron a la catástrofe de aquellas guerras) y los 30 citados por las fuentes, de los cuales se nombra como civitates a 23, mientras otros, como Dessobriga, Amallobriga, Septimanca, Nivaria y Acontia, aparecen en los itinerarios ${ }^{3}$ En la etapa presertoriana, el número de ciudades-estado o circunscripciones territoriales ciudadanas autónomas, que describiremos más adelante y a las que extenderemos también el nombre romano de civitates, debió de ser mayor, pues no habían desaparecido todavía núcleos de primer orden como los de Melgar de Abajo, Toro, Cuéllar o Pinilla Trasmonte, entre otros. Si los sumamos a las 28 ciudades supervivientes en época romana, y teniendo en cuenta que apenas pasan de 60 los asentamientos existentes en total, muchas de las civitates prerromanas habrían tenido un único núcleo de población, y un análisis detenido revela que el modelo de ciudad-estado uninuclear debió de ser la norma al este del Pisuerga. Nada parecido, pues, a la pirámide habitual en otros territorios.

Junto al corredor del Pisuerga se insinúa alguna excepción, como sería el caso de los dos pequeños asentamientos de Tabanera y Valdecañas, que pueden suponerse vinculados a Palenzuela (la Pallantia de las Fuentes clásicas de la época de conquista, no la de Ptolomeo), o el caso atípico de Gorrita y El Soto de Medini1la, dos núcleos situados casi frente por frente a ambos lados del Pisuerga, de difícil interpretación (¿ciudad binuclear?, ¿dependencia del primero respecto del segundo?). En el Carrión, parece lógico asignar a Lacobriga no sólo lo que sería su importante núcleo urbano situado bajo la actual población de Carrión de los Condes, sino también el enclave, por lo demás, mal conocido, de Población de Soto, situado cerca de aquél.

Pero es en la Tierra de Campos vallisoletana $\mathrm{u}$ occidental donde el paradigma se desdibuja en mayor medida. Salvo Tiedra ( $A m a-$ llobriga?) y Montealegre (iIntercatia?), de incuestionable entidad urbana, que controlan este espacio desde la cornisa del páramo de Torozos, y Medina de Rioseco, los demás centros de población (en número de 6 ó 7) se sitúan en la franja de las 3-6 ha de extensión, siendo el más pequeño el de Tordehumos, con tan sólo 1,3 ha. No obstante, su ubicación en el territorio no dibuja una disposición clara en torno a unos lugares centrales y no permite apreciar bien las dependencias jerárquicas. Como se ve, son además enclaves de cierta entidad. Queda la impresión de que la concentración que, como veremos, se desarrolló en favor de algunos centros durante el siglo IV a.C., en este sector no absorbió todas las antiguas aldeas, sino que excepcionalmente sobrevivieron algunas que permanecerían dependientes de aquellos. Ya junto al Duero, el poblado del cerro del Viso, en Bamba, podría estar vinculado a Albocela (la Arbucala que se cita con motivo de la expedición anibálica por el interior, en Villalazán). 
No pueden considerarse en este apartado algunos asentamientos pequeños situados en el entorno inmediato de los grandes núcleos urbanos, que deben entenderse más bien como partes complementarias de los mismos (barrios, acrópolis, etc.). En el otro extremo, queda la sospecha de que algunos núcleos como Pallantia o Intercatia, que adquieren un claro protagonismo en las Fuentes de época de conquista, estuvieran constituyéndose en centros jerárquicos en un nivel superior al estado ciudadano que constituye el modelo habitual, pero el aislamiento de las ciudades y la falta de presión demográfica y económica no eran favorables a este proceso, como veremos.

Para no inducir a error, conviene enfatizar un hecho que parece paradójico: la ausencia de jerarquía fue la consecuencia de una jerarquía extrema en el momento de formación de las ciudades, cuando algunos núcleos se convirtieron en el centro de fusión de las múltiples aldeas preexistentes. Después, consumado el proceso de concentración, la falta de presión demográfica hizo innecesaria la fundación de aldeas subsidiarias, resultando la imagen engañosa de poblamiento no jerarquizado.

Resumamos: el poblamiento del conjunto del sector sedimentario de la Meseta responde, pues, a un modelo de núcleos grandes y distantes entre sí, situados en su mayoría al norte del Duero, ceñidos a los valles de los principales ríos regionales, dominando los espacios de vegas más amplias y dejando vacíos los páramos y las llanuras arenosas del sur del Duero. De lo que se deduce que no existió una distribución homogénea de la población en el territorio. Como ocurre con frecuencia, factores diversos inducen una distorsión de la malla o retícula ideal (Hagget 1976). En el territorio que aquí se estudia fueron las pautas rectoras del poblamiento las que actuaron como factores de distorsión, produciendo como resultado una ocupación diferencial.

\section{La ciudad y su entorno}

En la aproximación desde el amplio marco regional a la ciudad, debemos hacer una pausa en el territorio ciudadano. Más adelante lo abordaremos en su vertiente política, la civitas, concebida como ciudad-estado. Baste ahora una breve referencia a la territorialidad, que debía de estar bien definida, ya que no se concibe el estado sin delimitación territorial. No son de extrañar, por ello, las abundantes referencias de los textos clásicos a los territorios propios de las ciudades en todo el interior peninsular, con ejemplos, en el ámbito que estudiamos, como los de Cauca (Apiano, Iber., 89) y Pallantia (Apiano, Iber., 83). Territorios que podrían haber estado amojonados, como ocurría en época imperial romana entre las ciudades de Salmantica, Mirobriga y Bletisa, en el territorio vettón, de acuerdo con los términos augustales que dan cuenta de ello.

En el Duero medio, la extensión de los territorios ciudadanos alcanzaría habitualmente varios centenares de kilómetros cuadrados (la media, en un reparto equitativo e ideal por núcleo, sería de $500 \mathrm{~km}^{2}$ ), con distancias del centro a la periferia que en algunos puntos alcanzarían los 20 kilómetros. Por ello, es improbable que todo el espacio estatal fuera objeto de aprovechamiento económico sistemático, por lo que el territorio de explotación habitual debía de ser más reducido, como se dirá más adelante.

\subsection{Emplazamiento}

La situación de la ciudad dentro de su territorio no es fortuita. $\mathrm{Si}$, con carácter general, se elegían puntos con dominio de amplias vegas, se observan también claras predilecciones en cuanto a la ubicación concreta:

- Acomodación preferente a los bordes de los páramos (que no se contradice con la desocupación interior de los mismos), aprovechando las condiciones estratégicas que ofrece la topografía en el frente erosivo sobre los valles: lenguas o salientes y plataformas destacadas en las cuestas o laderas, fácilmente defendibles, con buen control visual de las vegas y fácil acceso a los recursos complementarios del páramo. Más de la mitad de los núcleos regionales presentan esta ubicación.

- Aprovechamiento de cerros-testigo. En cierto modo, se puede considerar una variante del caso anterior, al ser estos cerros un accidente más de la variopinta fenomenología erosiva 
de los bordes de los páramos, de los que han quedado desgajados. No obstante, es significativo el número de ocupaciones singulares entre estos emplazamientos, ya sea por su extensión, que está determinada por el propio cerro, o por su funcionalidad. Emplazamientos de este tipo son: Olmillos de Sasamón (probablemente el solar original de Segisamon, con una extensión de 26 ha) y Calzadilla de la Cueza (Viminatio). Los asentamientos de Tordehumos y Bamba, que se encuentran entre los escasos de menos de 5 ha (menos de 2 en el caso de Tordehumos) se explicarían por razones estratégicas. En Castrojeriz, el caserío no se limitaba al cerro, sino que se desparramaba por las laderas y el llano, ocupando varias hectáreas más de lo que se sospechaba hace algunos años.

- Instalación en la terraza fluvial. Aunque minoritarios, no son tampoco raros los asentamientos en el fondo de los valles: Padilla de Duero, Soto de Medinilla, Valoria la Buena, Tariego de Cerrato (en una estrecha franja al pie del páramo que cae sobre el Pisuerga), Palenzuela, Villagarcía de Campos, Villalazán y Carrión de los Condes. Suelen ceñirse al borde de la terraza inmediata al río. Éste hace las veces de foso natural, disponiéndose defensas artificiales en el resto de su perímetro.

Coca, Matapozuelos, Palenzuela y Fuentes de Ropel, que encajan en alguno de los parámetros anteriores, aprovechan además la ventaja estratégica que ofrecen las horquillas fluviales.

Con carácter general, y como resumen, se puede decir que los núcleos ocuparon emplazamientos inmediatos a las vegas que constituyeron la parte principal de su territorio de explotación, bien en el mismo valle o, con preferencia, en alguno de los accidentes del borde del páramo, aprovechando el control visual del valle y las condiciones defensivas, que no obstante no fueron determinantes, valorándose también la facilidad de acceso.

\subsection{El núcleo urbano}

La ciudad propiamente dicha alcanzaba habitualmente un tamaño entre 5 y 20 ha, y hay indicios suficientes para afirmar que, con algunas excepciones, la mayor parte tuvieron una alta densidad de ocupación.
A falta de excavaciones extensas (la mayor parte de las excavaciones de viviendas no alcanzan la totalidad de la planta), disponemos ahora de unos documentos extraordinarios sobre el particular: las fotografías aéreas (del Olmo y San Miguel 1993; del Olmo 1996; del Olmo 1999; del Olmo 2006; http://usuarios.multimania.es/arqaerea/). Gracias a ellas, conocemos las plantas notablemente íntegras de varios núcleos: Tiedra, Valoria, Palenzuela, Calzadilla de la Cueza, Castrojeriz, Padilla de Duero, Mota del Marqués y Fuentes de Ropel, una ciudad astur que, sin embargo, se asemeja en su urbanismo y en su cultura material a las del centro de la cuenca.

El aspecto que más llama la atención, de entrada, es la planificación: Se trata de ciudades que no han crecido desordenadamente, sino que tienen una ordenación regular que responde a un plan unitario.

Los asentamientos de Calzadilla de la Cueza (Viminatio), Fuentes de Ropel (Brigeco) y Tiedra (¿Amallobriga?), de indiscutible entidad urbana, responden a un esquema simple de vía longitudinal que articula el conjunto y múltiples calles que la cortan transversalmente, haciendo a veces un pequeño quiebro en la intersección. El ejemplo más puro es el de Viminatio (fig. 2) mientras que en Brigeco (fig. 3) la calle principal corre oblicuamente a las trasversales atravesando en diagonal el núcleo entre lo que serían los dos accesos desde el Esla y desde el Cea. En Tiedra, además de la calle central, se insinúan otras dos calles abrazando el conjunto, disponiéndose entre ellas las vías trasversales (fig. 4). Se trata, en todo caso, de un esquema que no se reduce, aunque lo recuerde, al muy habitual en el mundo ibérico de vial central único con viviendas laterales adosadas a la muralla pero sin calles trasversales. Es, sin embargo, un modelo similar al de Numancia, donde hay dos calles longitudinales cortadas por otras perpendiculares a ellas.

Por si se dudara del carácter indígena de esta planificación, resulta significativo el urbanismo muy ordenado de dos ciudades que no sobrevivieron a la guerra sertoriana, Palenzuela (fig. 5) y Valoria (fig. 6) (aunque aquí algunos materiales romanos -muy escasos- atestiguan que se mantuvo alguna población). En esta última, la trama vial está más desarrollada que en las anteriores, con todo el espacio ocupado por un 


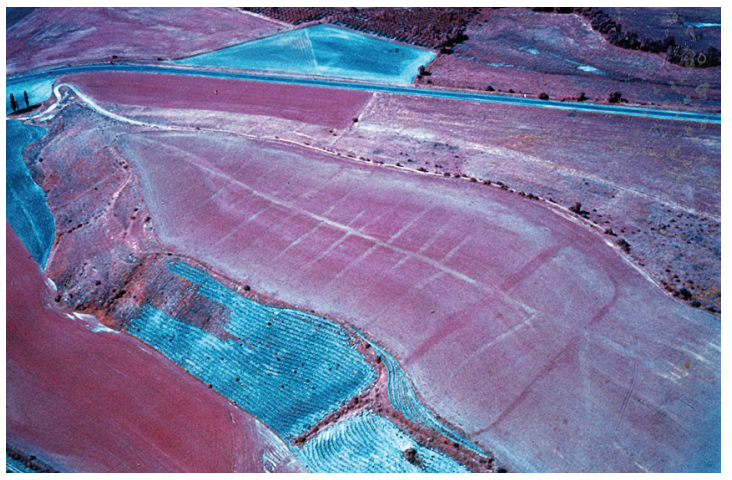

Figura 2.- Vista aérea de Viminatio (Calzadilla de la Cueza, Palencia) (del Olmo 1999).

emparrillado de múltiples calles que se cruzan en ángulo recto. También en "La Ciudad" de Paredes de Nava se aprecian calles más o menos rectas, junto a otras de trazado más descuidado y formando un entramado más irregular que en los casos anteriores (Pérez Rodríguez y Abarquero 2010, sobre fotografía de J. del Olmo).

Padilla presenta un desarrollo urbanístico verdaderamente impresionante (fig. 7), pero que plantea especiales dudas en cuanto a qué pueda haber en él de romano (Sanz y Romero 2007).

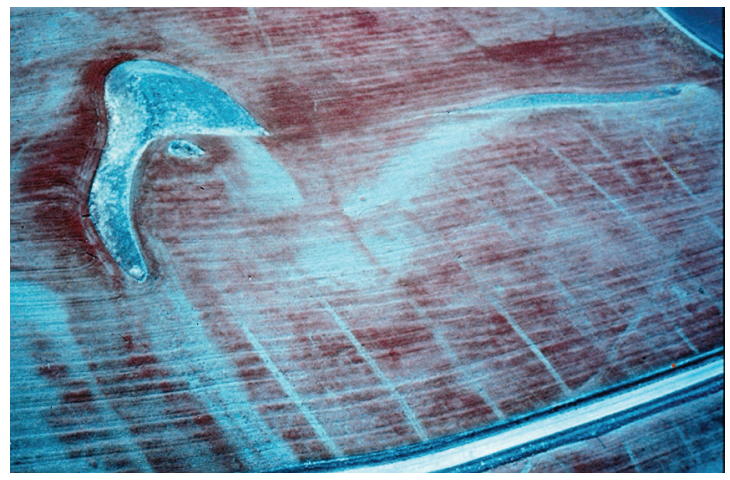

Figura 3.- Vista aérea parcial de Brigeco (Fuentes de Ropel, Zamora) (del Olmo 1999).

A esta etapa parecen corresponder al menos las dos amplias avenidas que se cruzan en ángulo recto, una de ellas cortando artificialmente un conjunto de calles paralelas que parecen anteriores. Estas calles probablemente anteriores delimitan las manzanas de unos 30 metros de anchura, en las que se disponen dos hileras de casas abiertas cada una a una calle y adosadas por una medianería trasera (a veces, como en Padilla, se dejaba una estrecha servidumbre intermedia que apenas permitía el paso de una

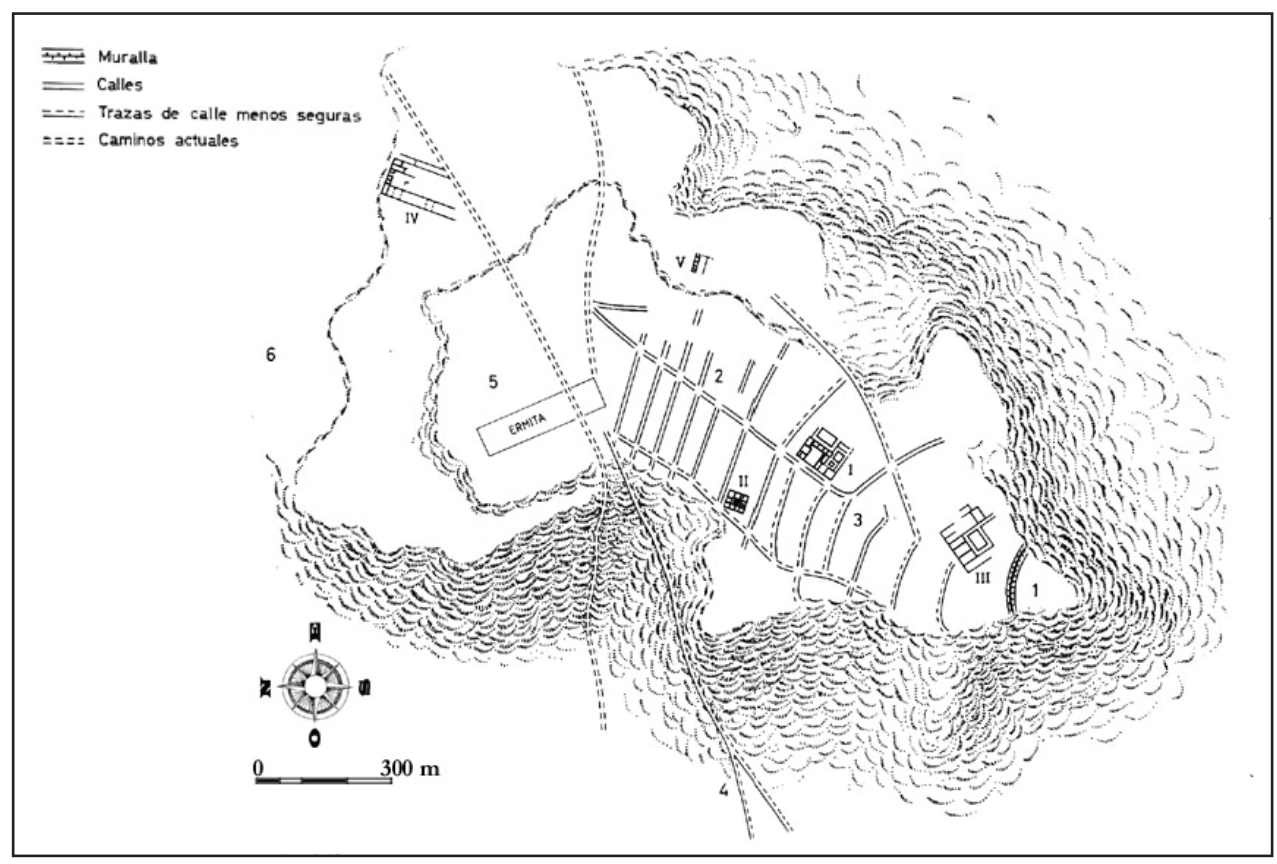

Figura 4.- Fotointerpretación del urbanismo de Tiedra (según del Olmo 1999). Se aprecian algunas domi romanas dentro y fuera de la trama urbana vaccea. 


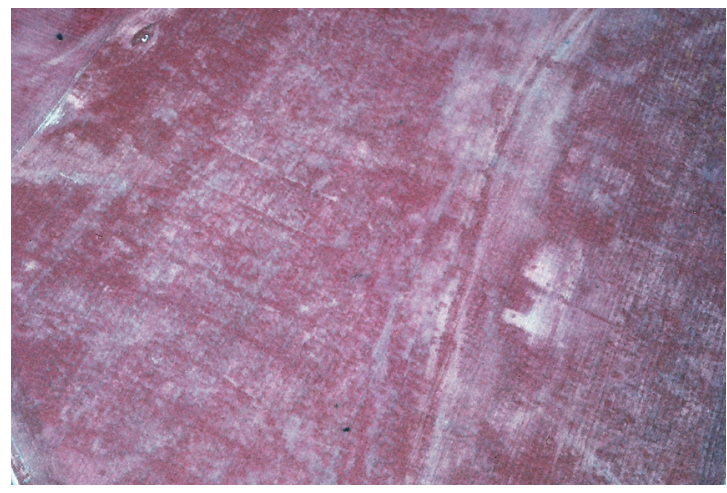

Figura 5.- Vista aérea parcial de Pallantia (Palenzuela, Palencia). Fotografía cortesía de J. del Olmo

persona). Esta es también, aproximadamente, la separación entre calles en Palenzuela y en Fuentes de Ropel. En Tiedra, la distancia entre los viales, que dejaría igualmente espacio para dos viviendas, parece algo menor. En Montealegre, las dos calles excavadas no son paralelas, sino que van convergiendo, probablemente hacia uno de los accesos de la ciudad, pero el esquema es el mismo, con dos hileras de viviendas, abiertas cada una a un vial (fig. 8). Un dato de interés es que aquí la fachada de las casas monta sobre las aceras, y que éstas se construyeron con ensanchamientos originales

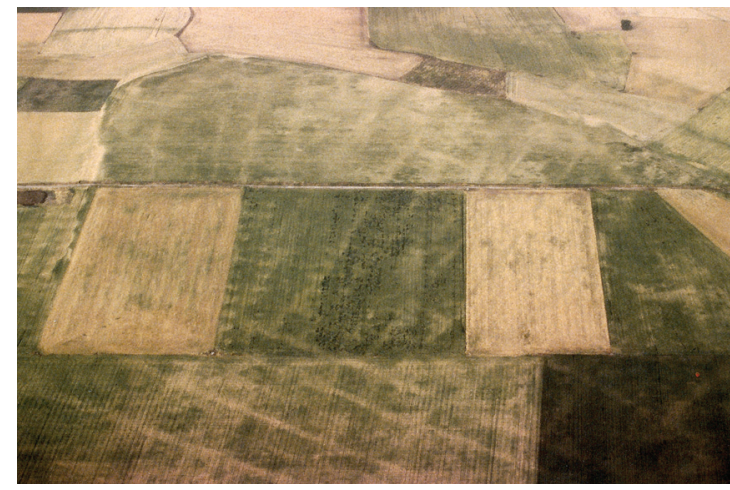

Figura 6.- Vista aérea parcial de Las Quintanas, en Valoria la Buena (Valladolid). Fotografía cortesía de J. del Olmo.

que configuran el zaguán de algunas viviendas. Se trata de un barrio nuevo de expansión de la ciudad, de vida muy corta, probablemente del periodo inmediatamente presertoriano, y el detalle anterior parece denotar un proyecto unitario que se ejecutó construyendo primero las calles con sus aceras y adaptando éstas a las casas que se montarían inmediatamente sobre ellas.

Junto a estas contundentes evidencias, la imagen aérea del poblado de Mota del Marqués revela un conjunto confuso donde las estructuras ortogonales conviven con otras circula-

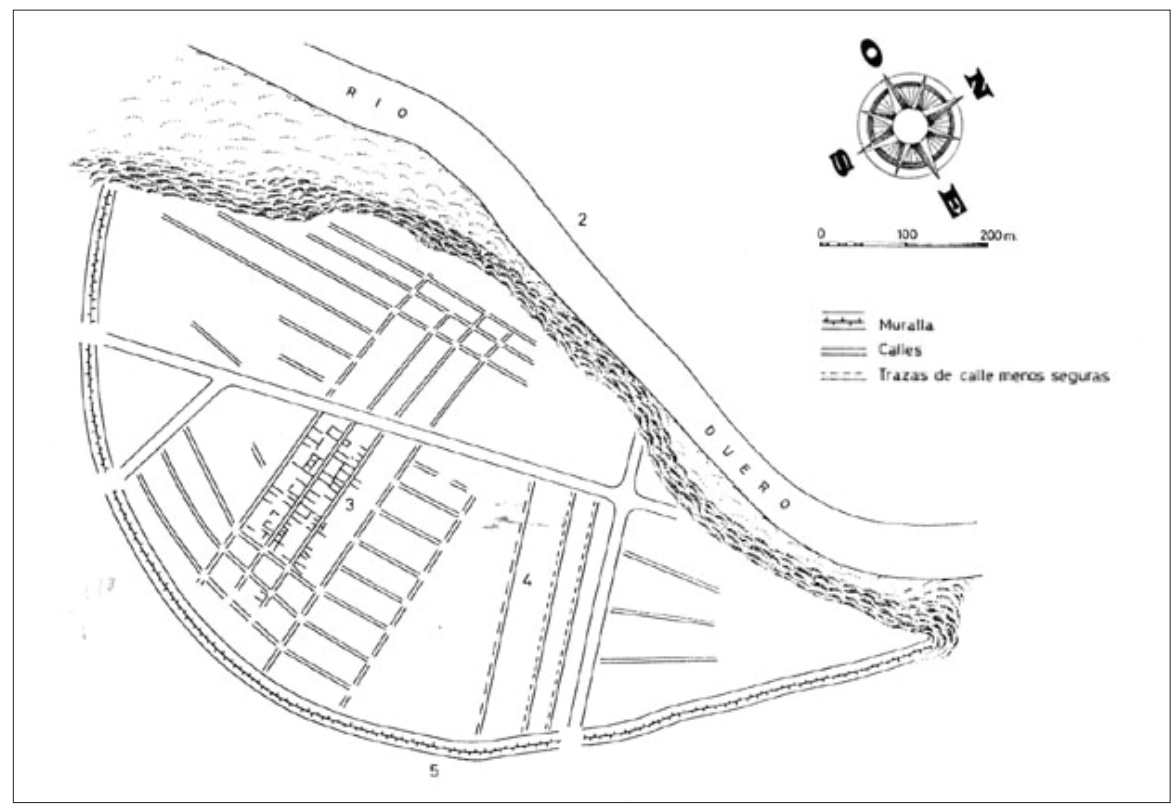

Figura 7.- Fotointerpretación del urbanismo de Pintia (Padilla de Duero, Valladolid) (según del Olmo 1999). 


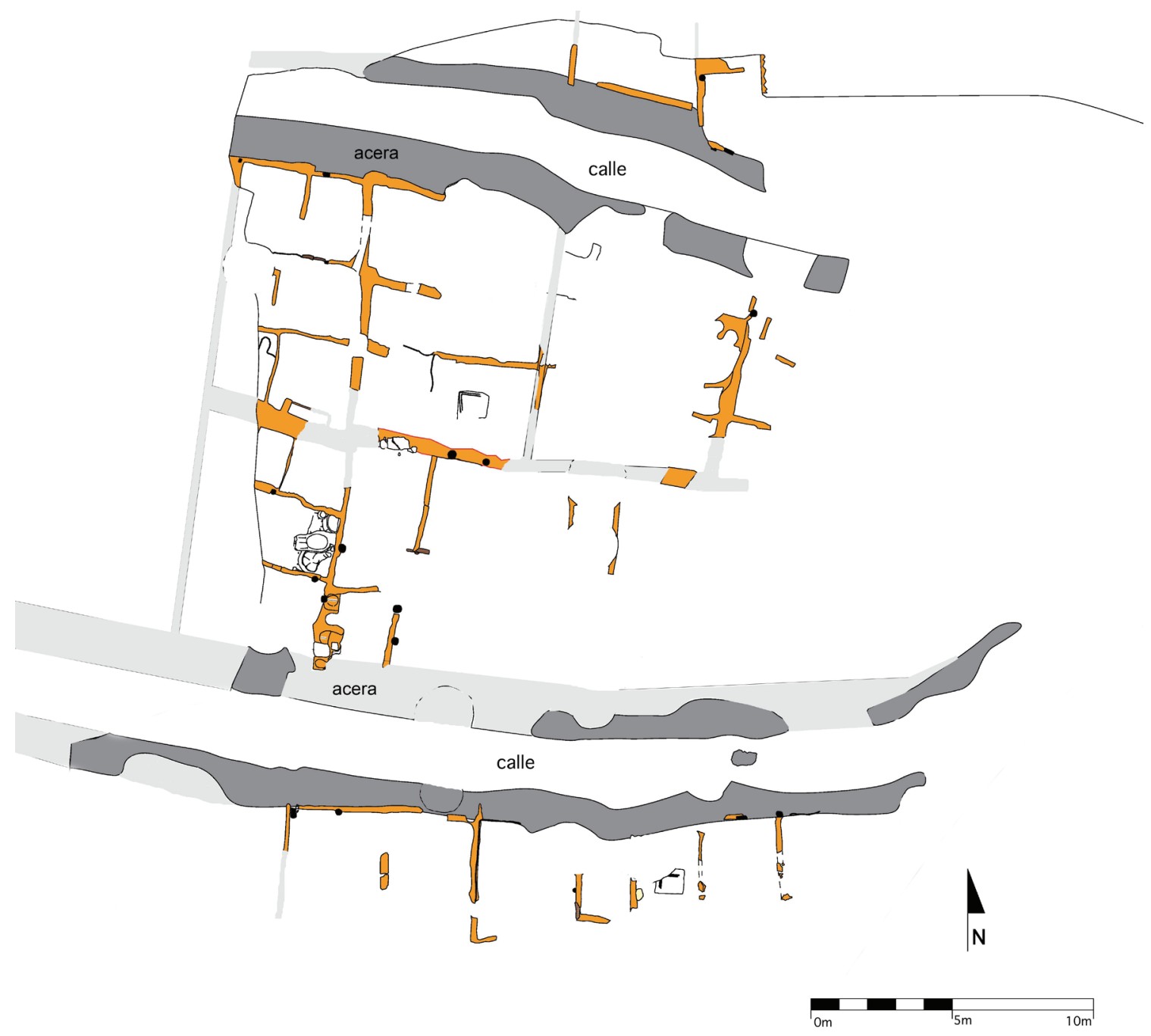

Figura 8.- Trazas urbanísticas parcialmente conservadas en un solar de Montealegre de Campos (¿Intercatia?). Cortesía de M. Retuerce.

res. Tal desorden, unido a una extensión que no alcanza las 5 ha., puede ser el exponente de esas pocas aldeas nacidas en la etapa del Soto que no desaparecieron en la fase del sinecismo y pasaron a depender de alguno de los centros urbanos, por lo que no desarrollaron el nuevo urbanismo que se impuso en éstos al tener que albergar a una población más numerosa. También se han documentado edificios circulares en algunos yacimientos importantes como Melgar de Abajo, Montealegre o El Soto de Medinilla (Cuadrado y San Miguel 1993: 319; del Olmo y San Miguel, 1993: 528; Escudero 1995). Visto lo anterior, no me detendré en los detalles del urbanismo en su nivel doméstico, salvo para recordar aspectos muy repetidos acerca del predominio de los espacios ortogonales; la construcción en adobe, raramente sobre cimiento de piedra, y a veces sobre vigas de madera, con paredes enlucidas y con pintura predominantemente blanca y roja en el interior; la utilización de postes de sustentación, así como de vigas y carrizo en las techumbres; los pavimentos sobre solera de cantos rodados o incluso de fragmentos de cerámica, con superficie de arcilla endurecida y a veces entarimados, como en algunas estancias de Montealegre y Padilla; los vestigios de pequeños es- 
pacios anexos de corral o cobertizos, como los que separaban las casas en Vertavillo (Abarquero y Palomino 2006: 45-46), o la existencia de silos o, en algunos yacimientos, como Roa, de minúsculos sótanos que recuerdan a los conocidos en Numancia, además de los hogares centrales, hornos de asar, vasares, etc.

Las plantas muestran una cierta variabilidad. Las viviendas más sencillas tenían unos $5 \mathrm{~m}$ de anchura. En Vertavillo (Abarquero y Palomino 2006), disponían de una habitación principal y una pequeña despensa o almacén posterior, además del cobertizo lateral; en $\mathrm{Pa}$ dilla (Centeno et al. 2003; Sanz, Romero y Górriz 2007), parece común un esquema de vestíbulo, estancia principal y pequeño ambiente posterior, pero son apreciaciones sobre plantas incompletas (fig. 9), y no faltan construcciones con un desarrollo más complejo en la misma Padilla, o en Roa (Abarquero y Palomino 2006: 87). Es de suponer que también existieran edificios de carácter público, que igualmente desconocemos. Y en cuanto a las calles, podían estar empedradas y disponer de aceras, como en Montealegre, Roa (Aratikos arqueólogos 2007) y Melgar de Abajo, donde también tenían canalón central (Cuadrado y San Miguel 1993: 315).

La mayoría, si no la totalidad, de los núcleos urbanos contaba, aunque en algunos no resulte hoy visible, con un sistema defensivo, que, con independencia de su función militar, probablemente tendría un importante valor simbólico como afirmación de la identidad ciudadana. La escasez de excavaciones impide una descripción detallada de los sistemas utilizados. Las murallas, al menos en algunos casos, delimitaban completamente el núcleo urbano, como parece ocurrir en el cerro testigo de Olmillos de Sasamón, en Tardajos, en La Nuez de Abajo (donde recibe el expresivo nombre de "El Cincho"), en Solarana, etc. En Valoria y Palenzuela, la fotografía aérea revela una amplia banda defensiva de cuarenta e incluso más metros de anchura con varias líneas de fosos y murallas. En Paredes de Nava, el cinturón defensivo parece estar constituido por dos murallas con sus respectivos fosos (Pérez Rodríguez y Abarquero 2010). En Padilla, la excavación emprendida en 2009, y todavía inacabada, en un punto de la línea defensiva, ha

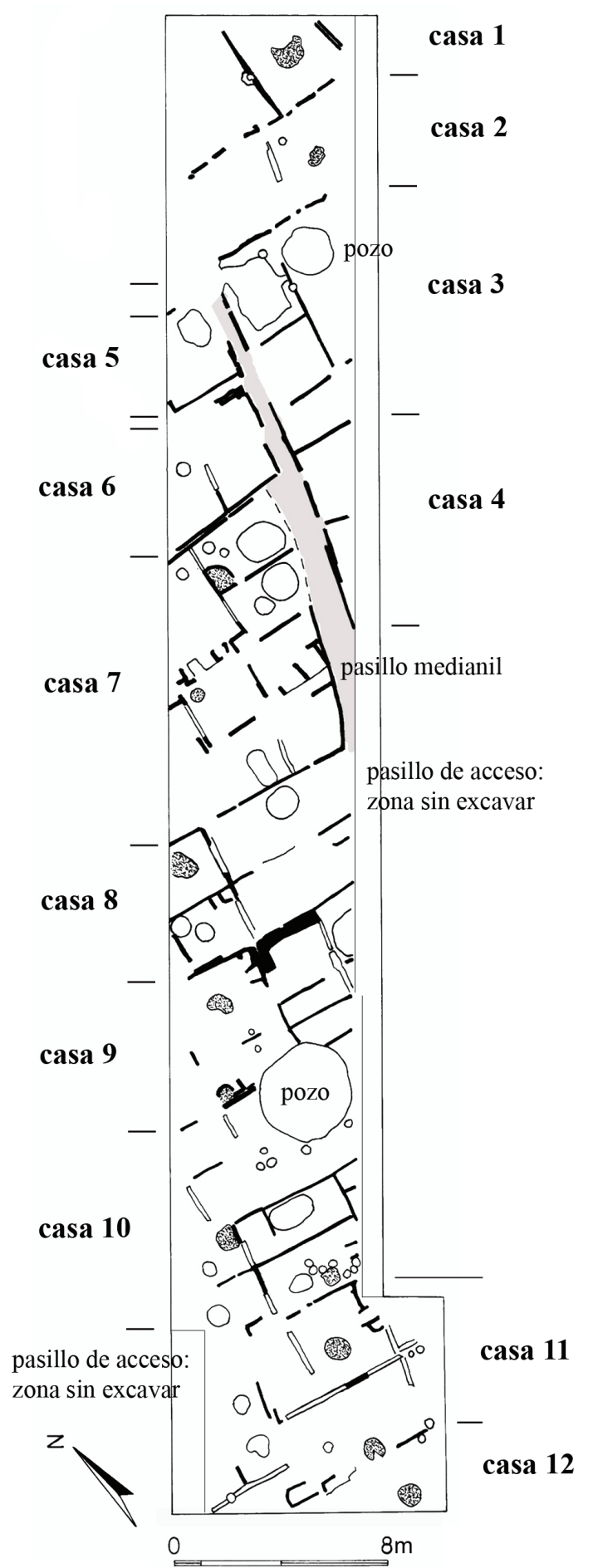

Figura 9.- Planta parcial de varias viviendas en Padilla de Duero (según Sanz, Romero y Górriz 2007). Se aprecian dos hileras contiguas por su parte trasera, que se abrirían a sendas calles fuera del área de excavación. 
descubierto una gran muralla de adobe de casi siete metros de espesor, con torres semicirculares y un foso de estructura compleja y casi cuarenta metros de anchura (Romero et al., en prensa). Tanto en Padilla como en Valoria, el río completaba el perímetro murado, mientras en Ubierna la muralla cierra el único lado que conecta la ciudad con la llanura del páramo, y el resto del contorno quedaba defendido por cortados rocosos.

En Pinilla Trasmonte, quedan tramos de muro perimetral, pero destaca especialmente la poderosa muralla de piedra que cierra el espigón del páramo donde se ubica la ciudad, con una estructura de amplia base, ataludada hacia el interior y vertical hacia el exterior, que debía de estar coronada por empalizada de madera y que se completaba, como en otros núcleos, con un amplio foso.

Aunque en la mayor parte de los casos las murallas estaban construidas en piedra, no faltan los muros terreros, como en Villapadierna, donde también se completaba con foso, y a veces se prefirió el adobe, omnipresente en la arquitectura doméstica. Así en la ciudad y en la acrópolis de Palenzuela, (cabe recordar, a propósito, el relato de Apiano - b. c., 1, 112- sobre el incendio de la murallas de Pallantia por Pompeyo); o en Padilla.

En Pinilla Trasmonte hay un segundo recinto exterior al caserío que recuerda a los existentes en otras áreas de la meseta, que suelen relacionarse con la guarda del ganado. También en Padilla hay un segundo recinto delimitado por un muro de grandes bloques de piedras sin desbastar (Mayoral y Crespo 2000), pero el equipo que desarrolla el proyecto de investigación en el yacimiento sospecha que pueda ser, más bien, un muro romano de asedio.

La defensa de la ciudad o del territorio ciudadano se completaba en ocasiones con una acrópolis. Así puede interpretarse el cerro inmediato al núcleo de Palenzuela, donde el microrrelieve permite adivinar un complicado sistema de muros defensivos que bajaban desde lo alto, dificultando la circulación por las laderas (el núcleo urbano tenía sus propia defensa de doble muralla). También el cerro de Pajares pudo servir de atalaya a la ciudad de Padilla, además de proporcionar la piedra para las estelas de la necrópolis, como señalan
Sanz y Escudero (1995). En cuanto al pequeño enclave del Cerro de la Miranda de Palencia, difícilmente puede considerarse un núcleo de población; probablemente fuera también un puesto de vigilancia dependiente del núcleo del Pico del Tesoro, situado enfrente, al otro lado del amplio valle del Carrión, sobre el que se conseguía un control desde los dos puntos, que además son intervisibles.

\subsection{La ciudad extramuros}

El núcleo urbano murado podía estar rodeado por otros elementos satélites, como son los sectores residenciales o artesanales desgajados, las omnipresentes escombreras y la o las necrópolis.

Algunas ciudades contaban con áreas residenciales extramuros, lo que recuerda el arrabal que mencionan las Fuentes en Helmantica (Polieno, 7, 48; Plutarco, Virt. Mul., 248e). Tariego y Montealegre tuvieron sendos asentamientos minúsculos en el entorno inmediato que no pueden entenderse sino como partes diferenciadas de la propia ciudad. Un caso distinto es el de La Cuesta del Mercado de Coca (Blanco 1994), un núcleo que se remonta a la Primera Edad del Hierro y no desapareció en la época en que surgieron los oppida. A pesar de tener 3 ha de extensión y su propia necrópolis, resulta difícil desgajarlo del conjunto ciudadano de Cauca, que tiene el centro urbano en Los Azafranales, a sólo unos centenares de metros de aquél; en especial cuando no conocemos ningún otro enclave en el entorno de Cauca, que fue una de las principales ciudades-estado vacceas. En todos estos casos, se trata de enclaves situados en las inmediaciones de la ciudad, dentro de su Territorio de Producción.

También quedaban fuera de los núcleos urbanos algunos sectores artesanales, en especial el alfarero, por necesidades de espacio y agua y quizás para evitar humos e incendios. Es el caso de Roa, Padilla, Tordehumos y Palenzuela. No obstante, en Coca, en un momento antiguo (s. III a.C.), hubo un alfar dentro del caserío, aunque en un sector marginal (Blanco 1998). En Padilla, es llamativo que los hornos conocidos se integran en lo que parece ser un auténtico barrio artesanal con su propia necró- 
polis, situado, como en Roa y Palenzuela, al otro lado del río. El ejemplo de Padilla recuerda el desarrollo similar de barrios artesanales diferenciados en algunos de los grandes oppida célticos europeos (Collis 1989).

Las ciudades del Duero medio tenían en su entorno escombreras que ocupaban amplios espacios y llegaban a rodear el núcleo urbano. Por su contenido, parecen haberse formado tanto por vertidos de basura (sellados a veces por capas de arcilla, tal vez por razones higiénicas) como de escombros procedentes de las frecuentes obras de construcción (Abásolo et al. 1983; Sacristán 1986: 149-154).

El paisaje del complejo urbano se completaba con la o las necrópolis, identificadas sólo en una minoría de las ciudades y situadas siempre a una distancia cómoda en los aledaños de las mismas. Necrópolis como la de Villamorón, en el territorio turmogo (Abásolo 1978), o la de Pinilla Trasmonte (Moreda y Nuño 1990), en el sector arévaco del ámbito de estudio, hunden sus raíces en las de la Primera Edad del Hierro. Pero las de Padilla (Sanz 1997), Palenzuela (Martín Valls 1984), Tariego (Castro y Blanco 1975; Fernández Jiménez et al. 1995) o Cuéllar (Molinero 1952; Barrio 1988) representan una novedad en el territorio vacceo, donde, como es sabido, no se conocen durante la Primera Edad del Hierro, debido probablemente a algún particular ritual funerario. El nuevo ritual de incineración apareció aquí hacia los inicios del siglo IV a.C., seguramente como una parte de la ola de cambio que entonces se produjo, en el momento en que, como veremos, empiezan a surgir las ciudades.

Las sepulturas debían de estar indicadas con alguna estructura visible, en particular pequeños amontonamientos irregulares de piedra, lo que explica el hecho de que el uso continuado de los cementerios respetara las tumbas más antiguas, dando lugar a una estratigrafía horizontal. En Padilla, las sepulturas se señalaban con estelas de piedra caliza (Sanz 1997: 460-466), a veces sin desbastar, pero otras con formas rectangulares; o bien ojivales, que recuerdan las conocidas en el cementerio tumular del final de la Primera Edad del Hierro de Ubierna.

En la misma Padilla, cerca de la necrópolis, entre ésta y el poblado, la fotografía aérea descubre un recinto rectangular de grandes dimen- siones $(125$ por $75 \mathrm{~m})$, delimitado, al parecer, por un foso, del que el equipo investigador sospecha que pueda tratarse de un espacio sagrado similar a los conocidos en otros ámbitos europeos (Sanz et al. 2003: 62-63), lo que entreabre un capítulo interesante para el futuro de la arqueología vaccea.

Para establecer la población de las ciudades no son fiables, desde luego, los números que aparecen aquí y allá en las Fuentes, como los 23.000 caucenses víctimas de las dos matanzas perpetradas por Lúculo (Apiano, Iber, 50), o los 20.000 hombres de a pie y 2.000 jinetes que poco después se reunieron en Intercatia (Apiano, Iber., 53). Sin embargo, sí es posible una aproximación razonable si se tiene en cuenta que la mayoría de los núcleos presentan todo el espacio ocupado por calles y manzanas de casas. El cálculo no sirve para aquellas ciudades de extensión desmesurada en las que tal grado de ocupación no está comprobado. En el supuesto de que las viviendas ocuparan un 70\% y los espacios públicos el 30\% restante, en una estimación generosa de $100 \mathrm{~m}^{2}$ (incluyendo corrales) y cuatro personas por vivienda, tendríamos 70 viviendas y 280 residentes por ha.; cálculo que está en línea con el efectuado para la Numantia del siglo I a.C. (Jimeno y Tabernero 1996: 429).

En este supuesto, un núcleo medio de 10 ha alcanzaría los 2.800 habitantes. Recuérdese que, sobre 47 enclaves de los que se conoce la extensión aproximada, al menos 37 tenían más de 5 ha (24 de ellos, más de 10 ha). Así que, de manera genérica, serían ciudades de entre 1.500 y 5.000 habitantes. Un oppidum como Pintia, que parece totalmente ocupado, llegaría, en esta estimación, a los 7.000 habitantes. Son cifras ciertamente llamativas, pero no veo razones para justificar cálculos a la baja. De todos modos, incluso en un escenario de 2.500 moradores de media por ciudad, en los $32.000 \mathrm{~km}^{2}$ del conjunto del área de estudio no se llegaría a 160.000 habitantes en total, con una densidad de $5 \mathrm{hab} / \mathrm{km}^{2}$.

\section{Economía}

¿Cómo podían ser económicamente viables semejantes aglomeraciones sin la aportación de aldeas tributarias? Me apresuro a decir que, 
puesto que de hecho existieron, no hay duda de que fueron capaces de atender sus necesidades, y consiguieron hacerlo con holgura, pues fueron visiblemente fuertes y prósperas. Los estudios ambientales y económicos (Delibes, Romero y Morales 1995; Cubero 1999; Romero y Ramírez 1999; Esparza 1999, etc.), aunque todavía escasos, suministran información de gran interés para empezar a entender el fundamento económico del modelo territorial.

Conviene hacer, previamente, una breve aproximación al medio ambiente del que se obtenían los recursos, que no variarían significativamente entre las diferentes ciudades. Tras un brusco enfriamiento en la primera mitad del siglo IV a.C. y un apreciable calentamiento durante la segunda mitad de la centuria, el clima se estabilizó en valores térmicos muy similares a los actuales durante los tres últimos siglos del milenio (Ibáñez 1999). Tampoco sería muy diferente el régimen pluvial, aunque la inexistencia de drenajes y la menor explotación de los acuíferos se traducía en una mayor escorrentía superficial y en una mayor disponibilidad hídrica que en el presente, con abundantes humedales en forma de lagunas, encharcamientos, etc. (Ibáñez 1999; Calonge 1995) de los que hay constancia en el entorno de muchos yacimientos, como Roa, Padilla de Duero o Montealegre y que recuerdan algunos episodios referidos por Apiano (Iber., 54 y 89) de aprovechamiento militar de este tipo de terrenos.

\subsection{Agricultura y ganadería}

Las ciudades dominaban una amplia extensión de vega -o de campiña-, bien desde el mismo fondo del valle o desde el borde del páramo, que permitía un amplio control visual. Cerca del poblado, o delimitándolo, estaba el río, con un régimen más variable que el actual por falta de regulación, y con desbordamientos estacionales. Las riberas arboladas eran más amenas, con chopos, álamos, sauces, fresnos y alisos, acompañados a veces de castaños, avellanos y nogales. Sobre los suelos silíceos, abundantes en los grandes valles, no faltaban extensiones de pinos resineros y piñoneros, en especial en algunos sectores regionales, así como alcornoques.
A la espalda de las ciudades se extendían las parameras, que antes de la progresiva explotación agrícola que no ha culminado hasta época reciente estaban ampliamente cubiertas de arbolado, en especial montes de encina, quejigo y sabina.

Aunque es difícil establecer su peso específico en relación con la ganadería, la agricultura fue sin duda uno de los pilares básicos de la economía, a pesar de que su reflejo en las muestras polínicas de los poblados sea más escaso de lo esperado. En el valle, o en las campiñas, estaban los campos de cereal, en especial de trigo común duro y en menor medida de otras variedades como la escanda, la esprilla o el trigo común compacto. La cebada se cultivaba en mucha menor cantidad que el trigo, mientras la presencia de mijo es puramente testimonial, como la de avena, que podría ser silvestre. Con la salvedad del mijo, se trata de cereales de ciclo largo, que se sembrarían en otoño y se recogerían en verano. No hay signos claros de cultivos de leguminosas, que a veces se alternaban con el cereal en la agricultura tradicional y servían para recuperar los campos. No obstante, el estiércol animal contribuiría a tal recuperación.

Podemos volver a preguntarnos ahora cómo pudieron ser sostenibles los grandes oppida regionales, con su boyante economía, y explotar su territorio sin la ayuda de aldeas satélites. Para ello, podemos elaborar un modelo hipotético de los requerimientos de tierra destinada al cultivo del cereal, que ocupaba la mayor parte del espacio agrícola, partiendo de una estimación razonable de rendimiento del trigo. Los cálculos publicados son muy dispares y proceden de la documentación de época medieval y moderna de los siglos anteriores a la mecanización del campo, que resultan siempre muy bajos, en el entorno de 1:4/1:8, propios de una economía de penuria que obligaba a roturar incluso terrenos muy poco productivos; o bien de las experiencias arqueológicas con trigos prehistóricos, con rendimientos mayores a los señalados e iguales o superiores a los híbridos actuales y más resistentes a las plagas (Reynolds 1988; Ibáñez 1999: 42-44). Por ello y por el aprovechamiento exclusivo de amplias vegas y campiñas ricas, se puede suponer durante la Edad 
del Hierro una productividad más alta que la citada de época histórica.

Teniendo en cuenta lo anterior, partamos ahora de una hipótesis de productividad media, para el trigo, de 1:10 (con rendimientos menores, la sostenibilidad del modelo se habría complicado). La siembra de 1 ha de terreno requiere aproximadamente $130 \mathrm{~kg}$ de semillas, por lo que con una producción de 1:10 se obtendría una cosecha de $1.300 \mathrm{~kg}$. A una media de medio $\mathrm{kg}$ diario por persona, una población de 1000 habitantes tendría unas necesidades anuales de $182.500 \mathrm{~kg}$ de pan, (un $\mathrm{kg}$ de pan viene a ser equivalente a un $\mathrm{kg}$ de trigo). Para producir esa cantidad, a $1.300 \mathrm{~kg} /$ ha, se requieren, en principio, sólo 140 ha. Ahora bien, sería necesario el barbecho para recuperar las tierras (no hay pruebas de rotación de cultivo cereal/leguminosas), por lo que, en un sistema de año y vez, la extensión precisa para el labrantío se duplica, hasta 280 ha. Todavía hay que sumar un $10 \%$ adicional para reserva de siembra y otro $10 \%$ para compensar pérdidas (debidas a ratones, insectos, etc.), con lo que llegamos a 336 ha (aproximadamente, una ha por cada tres personas). Esto, en lo que se refiere al trigo. Pero, además, se sembraba cebada, necesaria para completar el pasto del ganado vacuno y equino. Suponiendo una dedicación a este cereal de un tercio de la tierra dedicada a trigo, serían precisas 112 ha, y llegamos a 448 ha, que se pueden elevar a 500 para contar con un remanente de seguridad. Es decir, $5 \mathrm{~km}^{2}$ de vega.

Una población de 3.000 habitantes necesitaría $15 \mathrm{~km}^{2}$ de vega o de campiña, accesibles desde el núcleo urbano sin excesivos desplazamientos, incluso en vegas que no superaran un kilómetro de anchura (y hay que tener en cuenta que casi siempre la anchura es mayor). Para mantener comunidades de 5.000 personas, se necesitarían ya $25 \mathrm{~km}^{2}$, lo que empieza a plantear dificultades para el acceso cómodo, en especial si se piensa que en el entorno cercano de la ciudad se dedicaban también extensiones adicionales a pastos o ejidos para el vacuno y el equino, pero, aún así, en una vega de $2 \mathrm{~km}$ de anchura no serían necesarios desplazamientos mayores de $7 \mathrm{~km}$ en cada sentido del valle. A partir de aquí, la capacidad de explotación comenzaría a complicarse y un crecimiento de la población exigiría explotar otras áreas.

Así que, con las lógicas diferencias marcadas por las características de cada medio particular (amplitud de la vega o campiña cercana, calidad del terreno, etc.), la sostenibilidad agrícola del modelo de poblamiento, con ciudades de hasta 5.000 habitantes parece perfectamente posible con unos rendimientos como los supuestos (y cabe suponerlos porque el sistema efectivamente funcionó y al parecer saludablemente, por lo que probablemente fuesen mayores, en especial si tenemos en cuenta que la documentación escrita parece sugerir la existencia de excedentes de trigo. Una productividad sensiblemente menor a la supuesta habría hecho inviable el sistema.

Pero la misma argumentación nos lleva a decir que el potencial de crecimiento de tales ciudades estaba claramente limitado, pongamos hasta un máximo de 10.000 habitantes en el caso más favorable, lo que requería $50 \mathrm{~km}^{2}$ de tierras agrícolas más los pastos cercanos. Las ciudades prerromanas de la Meseta no habrían podido superar ese límite extremo sin romper el modelo de núcleo único, poniendo en explotación otras partes de su territorio desde aldeas satélites y sin cambiar drásticamente su tecnología y su sistema económico. Y como esto no sucedió, debemos suponer que dicho modelo de ciudades sin aldeas no agotó su capacidad de crecimiento demográfico; o, desde otra perspectiva, utilizando una expresión de la ecología, no agotó su capacidad de carga (que viene dada por los recursos disponibles en función de la tecnología), ni la del conjunto de la cuenca sedimentaria ni la del Territorio de Producción de cada ciudad; salvo, tal vez, en algún caso excepcional como el de Palenzuela, si ésta fuese la explicación de la fundación de dos aldeas (en Valdecañas y Tabanera) presuntamente dentro de su territorio político, sólo parcialmente explotado. Recordemos, por otra parte, que en la Tierra de Campos el sinecismo del siglo IV a.C. respetó algunos poblados que quedarían como tributarios de aquellos otros que se transformaron en centros urbanos. En estos casos, el modelo es ligeramente distinto y se amplía la capacidad de crecimiento demográfico del complejo ciudadano. 
El otro gran pilar económico era la ganadería, aunque de nuevo hay que recordar que desconocemos su importancia en relación con la agricultura. El dato más relevante es el predominio absoluto del vacuno (siempre por encima del $60 \%$ del peso total de los conjuntos faunísticos), en régimen de semilibertad a juzgar por la falta de los estigmas óseos propios de ejemplares estabulados, lo que sugiere la disponibilidad de pastizales más abundantes que los actuales gracias a la mayor humedad superficial. La paja y la cebada completarían la dieta de esta cabaña, que no sólo proporcionaba leche y carne, sino también estiércol y la fuerza de carga y tiro para las carretas y arados, como indica la existencia de animales castrados, todo lo cual era una aportación fundamental para la producción agrícola. Vacuno y cereales se complementan, pues, en algunos aspectos, pero también compiten por el espacio, por lo que la conjunción de estos elementos demanda un delicado equilibrio (Ruiz y Molinos 1992: 107).

La cabaña de ovicaprinos, con claro predominio de la oveja sobre la cabra, aún siendo importante, era muy inferior a la anterior, con una participación en los conjuntos faunísticos que habitualmente está entre el 9 y el $15 \%$ del peso total. El predominio de ejemplares adultos sugiere un aprovechamiento preferente de los productos secundarios, como la leche y la lana, sobre la carne. En especial, la producción de lana debía de ser notable para abastecer la amplia actividad textil. Por lo demás, el Territorio de Producción de las ciudades podía mantener perfectamente los rebaños gracias a los rastrojos, herbáceas de las cuestas de los páramos y pastos de monte. La trashumancia, sobre la que se viene teorizando con opiniones encontradas (Salinas de Frías 1997; Sánchez Moreno 1998; Esparza 1999; Cerdeño et al. 1999: 283; Burillo 1999: 555, etc.) y que es una estrategia posible, aunque no demostrada, en otras áreas, es en el Duero medio un recurso innecesario sobre el que se ha especulado con escaso fundamento, atribuyéndola incluso un papel principal en la ordenación del territorio en torno a unas supuestas cañadas protohistóricas, sobre la base de un falso protagonismo de la ganadería ovina (Sierra y San Miguel 1995).
La cuadra equina aporta en torno al 5\% del peso faunístico total (sumando caballos y asnos); menos que durante la Primera Edad del Hierro. No muestra signos de descuartizamiento (como ocurría en la etapa anterior en el yacimiento de El Soto de Medinilla), lo que, junto con el predominio de ejemplares adultos, indica su utilización preferente para el tiro y la monta. Las Fuentes refuerzan este aspecto con las referencias a la caballería de Cauca, Intercatia y Pallantia (Apiano, Iber., 51, 53 y 55).

En los corrales domésticos podían estar presentes las gallinas, aunque son muy poco frecuentes en las muestras estudiadas. Y en ningún poblado faltaban los perros, que sin duda tuvieron un papel importante en la guarda del ganado.

Agricultura y ganadería tuvieron un complemento en la recolección y en la caza. La primera debía de tener cierta importancia, en especial en lo que se refiere a las bellotas, que no sólo comían los cerdos. En muchas sociedades han constituido una parte básica del sustento humano y una reserva alimenticia de primer orden. Durante la protohistoria, se recogían en abundancia en los montes de las parameras meseteñas y se consumían habitualmente, para lo cual era preciso eliminar los taninos mediante algún procesamiento, como el molido y el posterior lavado. Con toda probabilidad, muchos de los molinos de mano, habituales en los yacimientos, se utilizarían, como en Numancia (Checa et al. 1999), precisamente para este menester.

Las masas forestales proporcionaban también material para la construcción (en especial madera de encina, quejigo, pino y alcornoque) y leña para el fuego, y constituían una reserva cinegética que aportaba una parte no despreciable de la dieta de carne, si se tiene en cuenta que los restos de fauna venatoria (sobre todo cérvidos, $\mathrm{y}$, en menor medida, jabalíes y conejos) supone en torno al $15 \%$ del peso en los conjuntos faunísticos de los poblados.

\subsection{Artesanía y comercio}

Nuestro conocimiento del sector artesanal es muy variable, como consecuencia de la representación selectiva de los productos en el 
registro arqueológico. También debía de ser muy desigual el grado de especialización e industrialización de las diversas manufacturas. Sin duda se pueden trasladar aquí algunos datos, siempre escasos, que se conocen mejor en la Celtiberia. Los herreros confeccionaban numerosas herramientas agrícolas muy similares a las que se han venido utilizando tradicionalmente hasta la mecanización del campo, así como otros muchos útiles (Barril 1992; Sanz, Romero et al., 2003), algunos de ellos al servicio de otros artesanos, como guarnicioneros o carpinteros, de los que apenas nada sabemos.

La actividad textil debía de estar basada exclusivamente en la lana y está bien atestiguada por la habitual aparición de pesas de telar e incluso de restos de lana almacenada en las viviendas (Romero y Górriz 2007; Sanz, Romero y Górriz 2007), que delata una artesanía predominantemente doméstica, lo que no está reñido con la gran capacidad de producción de la que da fe el relato de Apiano (Iber., 54) sobre la entrega de miles de sagos o capas por parte de los intercatienses a los romanos.

La actividad mejor documentada, por la abundancia y perdurabilidad de sus productos es la alfarería, que alcanzó un carácter semiindustrial, a juzgar no sólo por su especialización, sino también por la estandarización de las producciones. No parece casual que uno de los hornos de Pintia, con una parrilla de 4,5 $\mathrm{m}$ de diámetro, sea el mayor documentado en la protohistoria peninsular (Escudero y Sanz 1993). La mano de obra predominantemente masculina que parecen denunciar las huellas digitales sobre la arcilla, podría ser indicio de tal especialización (Sacristán 1993; Sacristán et al. 1999). Los talleres se instalaban, como ya dijimos, en las afueras de los poblados, buscando la cercanía del agua (más que los terreros de arcilla). La discusión sobre la amplitud de los mercados parece ir decantándose por el ámbito local, por cuanto no sólo hubo alfares en los grandes centros como Coca, $\mathrm{Pa}$ lenzuela, Padilla o Roa, sino también en un poblado como Tordehumos que es uno de los raros núcleos de pequeño tamaño.

Como hemos dicho, se fabricaron productos muy estandarizados, tanto en lo que se re- fiere a la calidad de las pastas y acabados como a las formas y decoraciones; y tanto en los diversos talleres como a lo largo del tiempo, de forma que se han podido caracterizar unas producciones clásicas perfectamente reconocibles desde la incorporación del torno durante la segunda mitad del siglo IV a. C., por lo demás masiva en toda la cuenca sedimentaria, hasta las guerras sertorianas. Sólo algunos detalles y productos específicos eventualmente presentes, como los vasos no torneados con decoración a peine que se siguieron fabricando al principio de esta etapa, u otros propios de los momentos finales como los vasos grises de acabado céreo y decoración estampillada, tan frecuentes en Coca (Blanco 1993; Blanco 2001), o determinadas decoraciones, sirven a veces de índices cronológicos.

La mayor parte de las formas y de los tipos decorativos no son originales, sino que tienen una clara raigambre ibérica y fueron incorporados, al parecer, por vía oriental, por el valle del Ebro y desde el Alto Duero, frente a las importaciones que habían llegado antes por vía meridional durante los siglos VI a IV a.C. No obstante, los monótonos conjuntos regionales son inconfundibles por la ausencia o escasez de algunas formas y la abundancia de otras, por el peculiar acabado de las pastas, por la generalización de la pintura negra y por otros detalles (Sacristán 1986: 160-208; Sanz 1997: 277-349; Escudero 1999). Son frecuentes los grandes vasos de almacenamiento de borde vuelto en forma de "palo de golf" o de "cabeza de pato", los cuencos, las copas de variado tamaño, etc. Vasos, todos ellos, decorados, habitualmente en su parte superior, con motivos pintados casi exclusivamente geométricos: semicírculos concéntricos, rombos, etc., formando secuencias de metopas y delimitados por estrías o molduras. Entre las producciones más características de la región, aunque en algún caso la desborden, están las grandes copas molduradas, los vasos trípodes y otros objetos singulares como las cajitas (de función controvertida: ¿saleros, quemaperfumes?), los sonajeros o las canicas. También parecen originales los "vasos de cocina", elaborados con barro refractario y que tienen muy poca variación formal. 
La gran crisis provocada por las guerras de Sertorio y Pompeyo (el filtro pompeyano, al que luego nos referiremos) afectaría al sistema productivo, de modo que, aun reconociéndose perfectamente la misma raíz técnica y estética, los productos posteriores son claramente distinguibles de los clásicos y constituyen un perfecto fósil guía de la nueva etapa postsertoriana o tardoceltibérica (Sacristán 1986-87; Sacristán y Pérez 1986).

Otra artesanía que, a pesar de su carácter elitista y su producción limitada, merece al menos un recordatorio es la orfebrería (Delibes et al. 1993; Delibes et al. 1996), que resulta singular por varias razones: porque sus diseños llegan a alcanzar calidad artística; porque, aunque con raíces claras en la joyería ibérica y del noroeste, desarrolló una tradición propia, la llamada orfebrería celtibérica, que tiene su núcleo, no en la Celtiberia propiamente dicha, sino en este sector del Duero Medio; porque es testimonio de una situación social y económica que lleva implícitas la disponibilidad de excedentes y su apropiación diferencial; y porque probablemente sus creaciones fueron fruto de unos pocos talleres regionales (aspecto que podría comprobarse mediante la analítica apropiada) que trabajaron para un mercado supralocal.

Esto nos conduce a un último sector económico: el comercio, sobre el que es difícil ir más allá de algunas consideraciones tópicas o muy generales, algunas de las cuales no dejan de tener interés para reflejar la situación global. Aunque la economía de las ciudades-estado debió de ser en buena medida autosuficiente en cuanto a los productos fundamentales, la falta de algunos recursos supone por lógica su adquisición a proveedores regionales o exteriores. En el cercano territorio autrigón, la ciudad de Salionca, junto a Poza de la Sal, se dedicó intensivamente a la explotación salinera, y, sin duda, al comercio de este recurso, pero también se podía obtener sal en el algunos sectores del interior de la cuenca sedimentaria, como en el entorno de las lagunas de Villafáfila, donde, aunque no haya confirmación para este momento, sabemos que se explotó habitualmente en etapas anteriores (Delibes et al. 1998). Toda la región del Duero medio carece absolutamente de algunos materiales como el granito, que, sin embargo, se utilizaba abundantemente (además de la arenisca que sí es endógena) para elaborar molinos, por lo que debía adquirirse fuera, probablemente a los vecinos del sur, de las tierras próximas al Sistema Central (Barrio 1999a: 30). También faltan en la cuenca sedimentaria los recursos metalíferos. Desconocemos, no obstante, las procedencias, las rutas y las modalidades de suministro, y de momento dependemos de los estudios que vienen realizándose sobre las posibles explotaciones mineras en las áreas vecinas (Barrio 1999a: 25-29; Barrio 1999b; Lorrio et al. 1999; Polo 1999; Esparza 1999: 98-10, etc.).

A falta de una economía monetaria propiamente dicha, no sabemos qué ofrecían a cambio las gentes del centro de la cuenca. Difícilmente se exportarían productos de lana, a pesar de su importancia, si se tiene en cuenta el predominio de la ganadería ovina en las economías los potenciales suministradores de metales. Parece más probable que se aportara trigo (en consonancia con lo indicado por Apiano -Iber., 87- sobre la compra de víveres por parte de los numantinos a los vacceos) y tal vez algún producto artesanal.

El comercio, aunque basado en el intercambio, no debe entenderse como un trueque primitivo, sino que en sociedades de este nivel económico se contaba con mecanismos bien formalizados, como reflejan los ponderales con marcas de valor, que han merecido interesantes estudios (García-Bellido 1999; Galán y Ruiz Gálvez 1996) en los que se propone la existencia de un sistema metrológico de amplio uso en áreas no ibéricas y plantean una economía con utilización de un auténtico "dinero" premonetal, interpretando, a partir del estudio de pesos, que tal utilidad se daría también a algunas joyas de plata del Duero medio, tales como los torques y los brazaletes acintados, que se recortarían para realizar los pagos.

En este ámbito duriense, sólo se acuñó moneda a partir de una fecha en torno al año 100 a.C. en Clunia y tal vez en Pinilla Trasmonte, donde apareció un molde para los flanes sobre los que se hace la acuñación, pero no entre los turmogos y vacceos que, sin embargo, acumularon ampliamente el numerario de plata. Los 
tesoros regionales, dejando aparte propuestas dudosas sobre su significado, avalan la capacidad de generar excedentes y de su apropiación diferencial, por cuanto, al menos en ciertos casos, parecen tesoros privados, como lo indica la multiplicación de escondrijos en ciertos yacimientos y la aparición de algunos de ellos en ámbitos domésticos.

\section{Identidad étnica, organización política y sociedad}

\subsection{Las etnias (Fig. 10)}

Las gentes que habitaron las ciudades del Duero Medio durante la Segunda Edad del Hierro son las primeras cuya identidad nos es revelada por la documentación histórica, que les da nombre, rostro y vida.

En un plano de identidad genérico, se sitúan los grupos étnicos, cuya territorialidad se reconstruye con bastante aproximación en el ámbito de estudio. Nos ceñiremos aquí a una descripción general, sin discutir los matices y advirtiendo de que los límites territoriales no deben entenderse como fronteras de unas inexistentes circunscripciones políticas étnicas. El territorio étnico, con sus límites exteriores, sería, en todo caso la suma de los territorios de las diversas civitates, que sí tendrían fronteras políticas, como se dirá más adelante.

El mayor grupo étnico regional era el de los vacceos, que ocupaban la parte principal y central de las tierras sedimentarias. Por el oeste, el límite con los astures parece bastante preciso en el río Esla (antiguo Astura), con la incertidumbre del interfluvio Cea-Esla en el noroeste, que podría ser territorio astur, aunque el poblamiento responda al modelo vacceo. Por el suroeste, el Tormes marcaría el tránsito al territorio de los vettones, a los que pertenecían Bletisa (Ledesma) y, según Ptolomeo, Salmantica, que no obstante se instaló en el lado que mira a los vacceos y se cita como vaccea con motivo de la campaña de Aníbal en el año 221 a.C.). Por el sur, sólo algunos núcleos como Cauca y Nivaria extienden el territorio vacceo más allá del Duero y de la extensa y desierta campiña arenosa de la Tierra de Pinares, pero no hay ningún argumento para prolongarlo más al sur, donde cambian tanto la geografía como las pautas de ocupación espacial (Barrio 1999a) y donde Segovia, con toda probabilidad, era la Segouia citada como arévaca. Por el este, la ciudad vaccea más oriental era Rauda, pero no se puede delimitar de modo preciso el territorio étnico en este sector oriental hacia el norte, no por dudas de atribución de las ciudades, sino debido a los amplios vacíos existentes hasta los núcleos arévacos occidentales. Por el nordeste hay también una pequeña incertidumbre en el contacto con los turmogos, que no sabemos si desbordaban el Pisuerga. Por el norte, el territorio vacceo probablemente se extendía hasta el pie de las estribaciones cantábricas.

Entre los vacceos, las fuentes de la etapa de conquista citan las ciudades de Pallantia (Palenzuela), Intercatia (¿Montealegre de Campos?), Cauca (Coca) y Octoduro (más tarde denominada Oceloduro, en Villalazán), además de Helmantica (más tarde Salmantica -Salamanca-), que suele suponerse vettona, siguiendo a Ptolomeo. Ya en época imperial romana, este autor atribuye a la etnia vaccea 20 poleis (Ptolomeo, Geographia, 2, 6, 49) (frente a las 17 civitates de Plinio-NH, III, 26-); entre ellas, además de las anteriores, estaban Viminatio (en Calzadilla de la Cueza), Lacobriga (Carrión de los Condes), Rauda (Roa) y Pallantia (Palencia, distinta a la Pallantia de las fuentes de la época de conquista, que no sobrepasó las Guerras Sertorianas), por citar las identificadas. Les asigna también algunas que debían de corresponder a otras etnias: Segisama Iulia, que Plinio, más fiablemente, atribuye a los turmogos, Segontia Paramica (que el propio Ptolomeo asigna en otro lugar a los várdulos), Sentike y Sarabris (quizás vettonas y seguramente fundaciones romanas). Ciudades vacceas no citadas por Ptolomeo fueron Septimanca (Simancas) y Amallobriga (¿Tiedra?).

El sector nordeste del espacio sedimentario lo ocupaban los turmogos, a los que resultaría difícil diferenciar de los vacceos de no ser por la asignación de ciudades en las Fuentes. $\mathrm{Su}$ territorio se extendía, de norte a sur, desde las estribaciones del Sistema Cantábrico (Las Loras) hasta el Arlanzón (más allá se abren extensos páramos vacíos surcados por los valles, también deshabitados, de los ríos Arlanza y Esgueva) y desde el Sistema Ibérico por el 
este hasta el Pisuerga, al menos, por el oeste. A ellos atribuye Ptolomeo Segisamon (Sasamón, pero el núcleo originario de época prerromana, tal vez, en el vecino castro de Olmillos de Sasamón), Deobrigula (Tardajos) y otras no identificadas: Bravum, Ambisna y Sisaraca. Esta última probablemente sea la Pisoraca de los Itinerarios, en Herrera de Pisuerga, que es fundación romana. Por su parte, Plinio añade Segisama Iulia, que Ptolomeo atribuye a los vacceos, y tampoco sabemos si era turmoga o vaccea la Dessobriga del Itinerario (en Osorno/Melgar de Fernamental). Por otra parte, en el territorio turmogo hay importantes núcleos como los de Castrojeriz, Villavieja de Muñó, La Nuez de Abajo y Ubierna, algunos de los cuales deben de corresponderse con las ciudades de identificación todavía incierta citadas por Ptolomeo.

Vacceos y turmogos fueron los pueblos que ocuparon el núcleo de la cuenca sedimentaria, pero la periferia albergó algunas ciudades de otras etnias que se rigieron por las mismas pautas poblacionales. La franja oriental, ya al pie del Sistema Ibérico, estuvo ocupada por un grupo de ciudades arévacas (Solarana, Pinilla Trasmonte, Arauzo de Torre y Clunia), alejadas de los asentamientos vacceos del centro de la cuenca y separadas por la sierra del territorio nuclear arévaco. Y en el otro extremo, Brigeco fue una cabeza de puente astur en el lado vacceo del Esla, como la vettona Salmantica en la orilla del Tormes abierta al espacio vacceo.

Las etnias fueron referentes identitarios. En su seno se forjaron especiales lazos de solidaridad que se expresaron en el autorreconocimiento frente a otros grupos, todo ello basado no sólo en la vecindad y en una cultura común (que podían compartir con otros grupos), sino además en una historia común, reforzada, probablemente, por la afirmación de un mismo linaje, real o mitificado. No obstante, que sepamos, este nivel étnico no tuvo un correlato político formalizado. Los lazos intraétnicos se verían fortalecidos por instituciones como el hospicio y redundarían en el apoyo mutuo y las empresas solidarias, en especial frente a amenazas exteriores como la romana, incluyendo quizás un caudillo o una autoridad coyuntural común; pero la soberanía, como

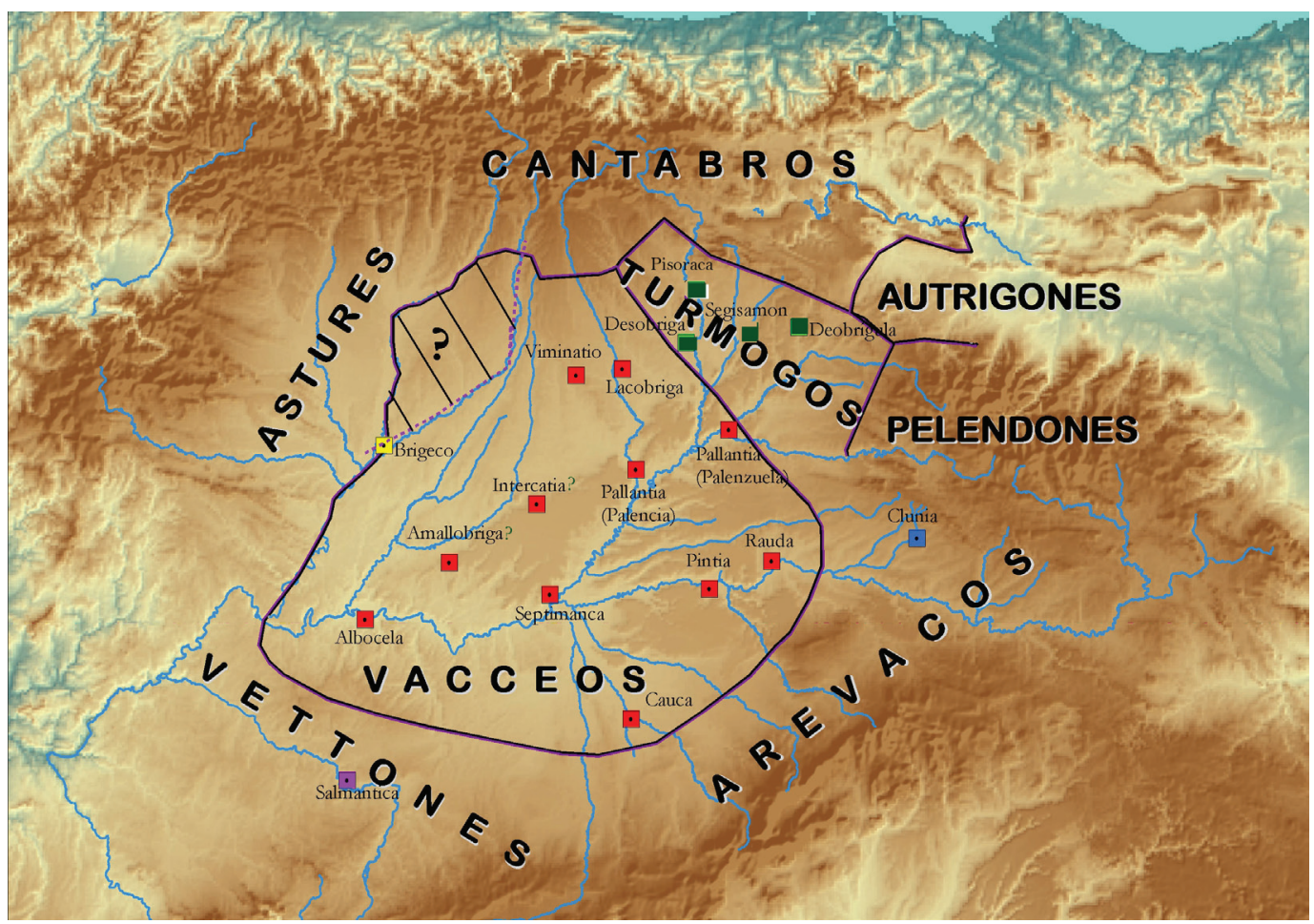

Figura 10.- Los grupos étnicos. 
luego veremos, residía en otro plano: el de las ciudades-estado.

Una cuestión aparte es la relativa a la integración de estos grupos del interior de la meseta en la superetnia celtibérica. Toda la región formaría parte de la Iberia de lenguas célticas a cuyos habitantes se refirieron genéricamente algunos autores, entre ellos Diodoro y Polibio, como celtíberos. No obstante, sabemos que los conceptos de celtíberos y Celtiberia se fueron acotando después por los romanos a algunos pueblos célticos en particular, quizás como consecuencia de un mayor contacto bélico con los mismos. El resultado habría sido, por una parte, la demarcación de la Celtiberia, con un contenido, por lo demás, no del todo claro y variable en el tiempo, cuyo núcleo duro sería el territorio de pelendones, arévacos, belos, titos y lusones (algunos de ellos no citados ya en época imperial); pero, por otra, el surgimiento, inducido desde el ámbito romano, de la conciencia de pertenecer a tal colectivo, con un sentido, por tanto, étnico. Lo que se expresaría, por ejemplo, en las denominaciones específicas como celtiber que acompañan a los antropónimos de algunos individuos, expresando origen, siempre en epígrafes aparecidos fuera de la Celtiberia (Lorrio 1997: 48)

No está claro si los vacceos y turmogos quedaban incluidos dentro de la superetnia celtibérica (al igual que los berones, a quienes Estrabón -III, 4, 12- reconoce como celtas, pero les sitúa al norte de los celtíberos), aunque compartieran muchos rasgos de cultura incluyendo, probablemente, el celtismo lingüístico, y aunque Apiano (Iber., 54), hablando de la vaccea Intercatia, se refiera a "esta región de los celtíberos". Pero Estrabón (III, 4, 13) y Livio $(35,7,6)$ mencionan en una misma frase a vacceos $y$ celtíberos, que quedan así diferenciados.

\subsection{El marco político: la civitas}

El marco político formalizado, como en las áreas vecinas, parece ceñirse estrictamente a las ciudades-estado o civitates, un término que la historiografia ha recogido de Plinio, que lo aplica a estas entidades en época imperial, cuando habían sido integradas en el nuevo marco administrativo. Su utilización retroactiva es sin duda anacrónica, pero apropiada, porque la administración imperial heredó y adaptó una realidad anterior al dominio romano, cuando las fuentes presentan a estas ciudades-estado como protagonistas de las guerras con Roma, con plena soberanía y autonomía de acción, que incluía la capacidad de pactar. Debe advertirse que Plinio utilizó también el término civitas con el sentido simple de "ciudad" (Capalvo 1986: 51-53; Burillo 2007: 253), pero la historiografía ha ido decantando la utilización en el sentido que le damos en estas líneas, prefiriendo otros, como "ciudad", o los latinos urbs y oppidum para los núcleos urbanos.

La civitas era tanto una circunscripción territorial con su centro urbano (la ciudad con su territorio bien delimitado) como una entidad política independiente, con su organización social. En el primer aspecto, además de la ciudadcapital (normalmente del mismo nombre, por lo que tienden a identificarse en el uso), podía tener otros núcleos de población, algo habitual en otros ámbitos. La peculiaridad del poblamiento en la cuenca media del Duero, con su escasa jerarquización, se traduce en que aquí, como ya hemos dicho, estas células políticas se limitaban con frecuencia a un único asentamiento urbano con su dominio territorial, con lo que la distinción entre ciudad y civitas es casi una formalidad académica.

Pero también está la vertiente política y social, en la que no se aprecian diferencias significativas con otras áreas. Con el surgimiento de la ciudad, la pertenencia a la misma pasa a ser un referente de primer orden para sus habitantes, que se convierten en ciudadanos de una determinada civitas. Es más bien poco lo que conocemos de su organización interna. Se pueden recordar las alusiones de las Fuentes al senado de algunas ciudades, que probablemente existía también en ciudades vacceas, interpretando un famoso texto sobre Cauca (Apiano, Iber., 5052). También debe suponerse la existencia de magistraturas, no sabemos si electivas, como lo eran las jefaturas militares en tiempos de guerra (aunque en tales ocasiones podían ser elegidas por toda una etnia -Apiano, Iber., 46- o por varias -Apiano, Iber., 45; Livio, 35, 7, 6-).

Desde luego, el carácter estatal de la civitas exigía una autoridad bien formalizada ya desde los primeros momentos. El intenso proceso de sinecismo -y la planificación urbanística con- 
comitante- no se puede considerar espontáneo, sino forzado, y dirigido o liderado por una autoridad incuestionada, como parece habitual en la formación de entidades estatales ${ }^{5}$.

Estas consideraciones nos permiten volver una vez más sobre el tan mentado como desconocido colectivismo de los vacceos; un tópico siempre sospechoso y sobre el que es difícil ir más allá de lo hipotético debido a lo parco de la referencia textual, pero que resulta consistente con el panorama que estamos presentando. El conocido relato de Diodoro (Bib. Hist. $V, 34,3)$, transmite una realidad de imposición del trabajo para la comunidad, de conscripción y reparto, igualitario o no, de la producción y de poder punitivo que no se corresponde con un escenario idílico de fraternidad e igualitarismo, sino de autoridad fuerte y coercitiva. Y ello sería así incluso si, como se ha postulado, este sistema de producción estuviera relacionado con el estrés bélico, es decir, con las excepcionales circunstancias de una economía de guerra (Salinas, 1990. Este autor, que recoge la bibliografía fundamental sobre el tema, insiste también en que no estaría vinculado a algún tipo de primitivismo, como otros han supuesto, sino que tuvo lugar precisamente en un ambiente urbano). No conocemos, sin embargo, el carácter de tal autoridad, indudablemente bien afianzada: ¿electiva, como los caudillajes numantinos en tiempo de guerra?, ¿hereditaria? (¿sería vacceo el "rey" Hilerno que dirigió a vacceos, vettones y celtíberos contra un ejército romano en el año 193 a.C -Livio, 35, 7, 6-?), ¿enraizada en el sistema gentilicio que pervivió en el marco urbano? En todo caso, el recurso a la antropología cultural sugiere que en sociedades complejas como las que tienen organización estatal, e incluso las llamadas "jefaturas", que están en un escalón inferior de complejidad, la autoridad tiende a hacerse hereditaria, dando lugar a lo que Diamond (1998: 303) ha denominado "cleptocracia": la conscripción legal de bienes para su redistribución y para el mantenimiento de un sector público y de clases no directamente productivas, pero también, en mayor o menor medida, para el propio enriquecimiento.

En el seno de las civitates perduraban y tenían reconocimiento expreso grupos de carácter aparentemente suprafamiliar o gentilicio, según refleja la epigrafía de época romana en todo el territorio céltico y como se aprecia en nuestro territorio de estudio en téseras de hospitalidad como las dos de Sasamón o las dos de Paredes de Nava, en las que tales grupos están representados por personajes, uno de los cuales es denominado princeps en una tésera de Paredes (en la de los Zoelas, fuera de nuestro ámbito, se les llama magistrados). Para la consideración de tales grupos, debe tenerse en cuenta la crítica que se ha formulado acerca de un entendimiento esquemático según un sistema de gentes, gentilitates y cognationes, que parece una construcción académica (Beltrán Llorís 1988).

Especialmente expuestas resultan las especulaciones sobre estratificación social, para lo que apenas se cuenta más que con alguna indicación aislada y de dudoso significado en las fuentes escritas, con los datos arqueológicos todavía demasiado escasos de los poblados y los de dudosa interpretación de las necrópolis, que requieren una exégesis siempre comprometida. El mundo de los muertos ofrece con frecuencia una imagen distorsionada de la sociedad de los vivos (Hodder 1988: 15), y así parece ocurrir en las necrópolis celtibéricas y en las del territorio de este estudio. El sesgo ritual podría traducirse en la invisibilidad o sobrerrepresentación de determinados grupos o colectivos sociales (Sanz 1997: 478; Jimeno 1999: 16). Pero, sin dejar de tener esto en cuenta, ciertamente las diferencias de los ajuares son manifiestas y deben reflejar la desigualdad social, aunque sea con alguna deformación.

El panorama en el Duero medio parece bastante similar al de algunas áreas celtibéricas. Las tumbas del cementerio de Las Ruedas de Padilla de Duero, el mejor conocido (Sanz 1997: 498-504; Sanz y Romero 2007), indican una estratificación que recuerda a la de la necrópolis de Numancia. Las tumbas masculinas muestran el rango militar (las aparentemente femeninas parecen responder a una escala comparable), con unos pocos ajuares llamativos con armas suntuarias y signos de autoridad y otros especialmente abundantes con armas más sencillas, además de algunas tumbas sin ajuar (de las que se ha insinuado que pudieran pertenecer a población dependiente, al estar en un sector que, a falta de conocer otras áreas de la necrópolis, se interpreta 
como reservado a guerreros), pero no sabemos qué otras implicaciones socioeconómicas tendría la jerarquía militar o la pertenencia a un determinado cuerpo. Conviene señalar que, con toda probabilidad, no habría un estamento militar como tal. Más bien, en las comunidades celtibéricas, sería el estatuto de ciudadano el que llevaría consigo la condición militar, que tuvo especial relevancia y dio lugar al surgimiento de un sentido caballeresco de la vida. Este sentimiento se refleja en nuestro ámbito de estudio en el episodio del intercatiense que orgullosamente retaba a combate singular a las tropas romanas (Apiano, Iber., 53) y en la heroización por los vacceos de los muertos en batalla, a quienes entregaban a los buitres, considerados animales sagrados (Eliano, $\mathrm{Na}$ tur. Anim. X, 22), una práctica que Silio Itálico (Pun., III, 340-343) atribuye genéricamente a los celtíberos.

En definitiva, la arqueología funeraria, por su carácter ritual y porque refleja aspectos ritualizados de la propia sociedad puede transmitir una imagen sesgada de ésta. Las diferencias de ajuar son significativas, pero plasman en primer término aspectos simbólicos. El ajuar funerario de un individuo no sólo expresa su riqueza, sino que es símbolo de su estatus (y tal vez sólo del estatus en un determinado orden o faceta de la sociedad) que no tiene por qué ir ligado de manera lineal al nivel económico, si bien es cierto que comúnmente el rango o el estatus, en sociedades estables, tiende a perpetuarse y a tener un correlato económico.

Tampoco los atesoramientos encontrados en los poblados informan realmente sobre el grado de desigualdad social mientras no se conozca su auténtica frecuencia y sus contextos. $\mathrm{Y}$ en cuanto a la posible existencia de un sector servil, que a veces se postula a partir de las referencias a siervos y población libre en $\mathrm{Hel}$ mantica (Polieno, 7, 48; Plutarco, Virt. Mul., 248e), si hay que conceder un fondo de veracidad a tales referencias, honestamente no sabemos cuál pueda ser su significado, que podría variar desde un sector de población clientelar hasta una incipiente cautividad derivada de la guerra; pero sería, cuando menos, problemático y arriesgado definir como esclavistas estas sociedades protohistóricas del interior peninsular.
En definitiva, hoy por hoy no resulta posible ir más allá de recordar algunos tópicos y simplificaciones aplicables a sociedades de parecido nivel o de interpretar dudosamente episodios o enunciados de las Fuentes que por ahora no trascienden lo anecdótico. Es éste uno de esos asuntos en que, a falta de información, sobra ruido, y habrá que confiar en que la información progrese por el aumento de la documentación arqueológica, tanto de los poblados como de las necrópolis, cuyo mayor conocimiento permitirá ir mejorando su interpretación.

\section{Evolución del poblamiento}

En páginas anteriores, he dibujado el poblamiento de la cuenca media del Duero como un cuadro estático que traduce el modelo exitoso que se impuso y se mantuvo sin cambios significativos durante casi toda la Segunda Edad del Hierro. Pero, este modelo, como realidad histórica, tuvo un origen a partir de otro patrón previo (véase Delibes y Romero en este mismo volumen) y con el tiempo terminaría chocando traumáticamente con el expansionismo romano, que incorporó los restos a su nueva organización administrativa. En este apartado se atenderá específicamente a estos aspectos.

\subsection{Origen del modelo de poblamiento $y$ del urbanismo en el interior de la Meseta}

La gestación del modelo urbano y territorial de la cuenca media del Duero muestra tanto rasgos comunes como diferenciadores con otros territorios. Entre los primeros, está la propia formación de los núcleos de carácter urbano que suelen denominarse oppida (porque habitualmente presentan una delimitación defensiva), que tuvieron un especial éxito en este territorio.

¿Cuándo y cómo se puso en marcha el proceso? Hay una línea historiográfica que, desde posiciones más bien teóricas, ha postulado que un rasgo tan complejo como el urbanismo desarrollado no se puede entender sin la intervención o el estímulo de una cultura urbana exterior que debería ser la romana, $\mathrm{y}$, desde esta 
perspectiva, sólo el intenso contacto que se estableció durante la conquista explicaría el origen de la ciudad en el interior peninsular. Otra corriente defiende que el surgimiento de los oppida y la implícita concentración poblacional serían una consecuencia y una de las principales expresiones del complejo proceso de celtiberización, por utilizar el término con el que suelen describirse los importantes cambios que, apoyados en mejoras técnicas, transformaron también la cultura material de los pueblos del interior, incluidos los de la Celtiberia histórica. En última instancia, sería reflejo de un movimiento iberizador, fruto del influjo de una periferia más progresiva -por contacto con el mundo mediterráneo- sobre el interior céltico. Aunque bien urdida, me parece poco creíble la explicación de la celtiberización como la expansión de un sistema cultural superior y completo elaborado en la Celtiberia histórica, incluida la lengua celtibérica, a buena parte del interior peninsular, que sería entonces celtizado (Almagro-Gorbea 1993).

Existen ya suficientes argumentos como para desvincular el origen de los oppida de la influencia romana y para afirmar un inicio anterior. Aunque en algunas zonas, como en la propia Celtiberia histórica, el proceso continuara durante la conquista y llegara a verse mediatizado por ella, como lo demuestran, entre otros, los casos de Complega y Sege$d a$, en el Duero medio, el desarrollo se operó en momentos más tempranos, durante el siglo IV a.C., y presumiblemente el modelo de poblamiento estaba ya constituido en sus rasgos fundamentales a comienzos del siglo III a.C. La arqueología no deja duda sobre la antigüedad del proceso, que se inició al final del mundo del Soto y presumiblemente ligado al proceso celtiberizador. Estamos ya en condiciones de enriquecer y matizar este punto de vista, más allá de su mera formulación.

La base está en el mundo de El Soto de Medinilla. A partir de un cierto momento, las gentes que habitaban en las viejas aldeas soteñas de las tierras sedimentarias del interior de la Meseta (en otros territorios del antiguo ámbito del Soto se produjo un desarrollo distinto) se fueron concentrando en un reducido número de asentamientos. De una constela- ción de poblados, que probablemente superaban el centenar y medio en este sector, se pasó a poco más de sesenta núcleos, casi todos ellos de indudable carácter urbano. Este movimiento de sinecismo supuso el abandono de la mayor parte de las antiguas residencias y la agrupación, no en nuevos enclaves sino en algunos de los preexistentes, siendo muy contadas las fundaciones en un nuevo solar, como Padilla de Duero y más dudosamente Palenzuela y Olivares -que aparentemente fue una fundación fallida, de vida corta-; o, los núcleos del interfluvio Esla-Cea, donde al parecer se reordenó el poblamiento en favor de nuevas fundaciones (Celis 1996; Celis 2007).

Este desarrollo resulta insólito, porque en otros ámbitos, incluso cercanos, la formación de la ciudad suele ir acompañada de la creación de múltiples asentamientos menores de nueva planta, que en el caso de los vettones, también durante el siglo IV a.C., llega al 77\% del total (Álvarez-Sanchís 1999: 106); situación que se repite en el oriente de la Meseta (Jimeno y Arlegui 1995: 108-109; Jimeno 2000; Heras 2000), por lo que se ha supuesto un incremento de población en esta etapa. Tal vez se debiera a que en estos ámbitos la geografía no proporcionaba a las ciudades, en sus inmediaciones, terrenos de cultivo suficientes para su autoabastecimiento, de forma que necesitaron explotar partes más alejadas desde aldeas dependientes.

Se van reuniendo ya bastantes datos que ilustran cómo se produjo el proceso. De los poblados del Soto que desaparecieron, muchos no llegaron a conocer el torno cerámico y en otros aparecen escasísimos vasos torneados "celtibéricos" que delatan el preciso momento de su desaparición, cuando el torno comenzaba a implantarse, durante la segunda mitad del siglo IV a.C. Quizás un excelente fósil pueda ser el asentamiento de Las Quintanas, en Castronuevo de Esgueva, una aldea del Soto que desapareció en ese momento de novedad del torno, pero donde la fotografía aérea revela ya una planimetría de calles rectas (del Olmo 2006: 337-338): una transformación urbanística truncada en sus inicios.

El punto de partida debe de remontarse a la primera mitad de la misma centuria. En Roa, el área del asentamiento creció entonces, desbordando ampliamente los límites del poblado 


\begin{tabular}{|c|c|c|c|c|c|}
\hline YACIMIENTOS & SOTO II & $\begin{array}{l}\text { S. IV } \\
\text { A.C. }\end{array}$ & $\begin{array}{l}\text { CELTIBÉRICO } \\
\text { PLENO }\end{array}$ & $\begin{array}{l}\text { CELTIB. } \\
\text { TARDÍO }\end{array}$ & ROMANO \\
\hline \multicolumn{6}{|l|}{ 1.-Villapadierna } \\
\hline \multicolumn{6}{|l|}{ 2.-San Cipriano de Rueda } \\
\hline \multicolumn{6}{|l|}{ 3.-Corbillos de los Oteros } \\
\hline \multicolumn{6}{|l|}{ 4.- Castrillino } \\
\hline \multicolumn{6}{|l|}{ 5.- Fuentes de Ropel } \\
\hline \multicolumn{6}{|l|}{ 6.-Barcial del Barco } \\
\hline \multicolumn{6}{|l|}{ 7.-Villamol } \\
\hline \multicolumn{6}{|l|}{ 8.-Melgar de Abajo } \\
\hline \multicolumn{6}{|l|}{ 9.-Villalpando } \\
\hline \multicolumn{6}{|l|}{ 10.-Molacillos } \\
\hline \multicolumn{6}{|l|}{ 11.-Zamora } \\
\hline \multicolumn{6}{|l|}{ 12.-Saldaña } \\
\hline \multicolumn{6}{|l|}{ 13.-Población de Soto } \\
\hline \multicolumn{6}{|l|}{ 14.-Carrión de los Condes } \\
\hline 15.-Calzadilla de la Cueza & & \multicolumn{3}{|c|}{ Supuesto, pero no comprobado } & \\
\hline \multicolumn{6}{|l|}{ 16.-Cisneros } \\
\hline \multicolumn{6}{|l|}{ 17.-Paredes de Nava } \\
\hline \multicolumn{6}{|l|}{ 18.-Castromocho } \\
\hline 19.-Palencia & \multicolumn{3}{|c|}{ Pico del Tesoro } & \multicolumn{2}{|c|}{$\rightarrow \quad$ Palencia-ciudad } \\
\hline \multicolumn{6}{|l|}{ 20.-Cuenca de Campos } \\
\hline \multicolumn{6}{|l|}{ 21.-Aguilar de Campos } \\
\hline 22.-Medina de Rioseco & & & & & \\
\hline 23.-Tordehumos & & & & & \\
\hline 24.-Villagarcía de Campos & & & & & \\
\hline 25.-Montealegre & & & & & \\
\hline 26-Tiedra & & & & & \\
\hline 27.-Abezames & & & & $i$ & \\
\hline 28.-Mota del Marqués & & & & & \\
\hline 29.-Torrelobatón & & & & & \\
\hline 30.-Villalazán & Los & astros/ & uevo/¿E1 Alba? & & \\
\hline 31.-Bamba & $i$ & & & & \\
\hline 32.-Toro & & & & & \\
\hline 33.-Tordesillas & $i$ & & & & \\
\hline 34.-Simancas & & & & & \\
\hline 35.-Valladolid-Gorrita & & & & & \\
\hline 36.-Vallad.-Soto Medin. & & & & \begin{tabular}{l|l}
$\mathrm{Val}$ \\
\end{tabular} & lolid-ciudad? \\
\hline 37.-Valoria & & & & & \\
\hline 38.-Vertabillo & $i$ & i & & & \\
\hline 39.-Tariego de Cerrato & & & & & \\
\hline 40.-Valdecañas & & & & & \\
\hline 41.-Tabanera & & & & & \\
\hline 42.-Palenzuela & $i$ & & & & \\
\hline 43.-Villavieja de Muñó & & & & & \\
\hline 44.-Castrojeriz & & & & & \\
\hline 45.- Osorno/Melgar & & & & & \\
\hline 46.-Olmillos de Sasamón & & & & $\rightarrow$ & samón \\
\hline 47.-Villadiego & & & & & \\
\hline 48.-La Nuez de Abajo & & & & & \\
\hline
\end{tabular}




\begin{tabular}{|c|c|c|c|c|c|}
\hline 49.-Ubierna & \multicolumn{3}{|r|}{ La Polera } & \multicolumn{2}{|c|}{ Montes Claros } \\
\hline 50.-Tardajos & \multicolumn{3}{|r|}{ E1 Castro } & \multicolumn{2}{|c|}{$\rightarrow$ Vega al pie de El Castro } \\
\hline 51.-Los Ausines & & & & & \\
\hline 52.-Solarana & & & & & \\
\hline 53.-Pinilla Trasmonte & & & & & \\
\hline 54.-Arauzo de Torre & & & & & \\
\hline 55.-Clunia & $i$ & \multicolumn{2}{|r|}{ Quintanarraya/Hinojar del Rey } & $\rightarrow$ & Peñalba de Castro \\
\hline 56.-La Vid & $i$ & & & & \\
\hline 57.-Roa & & & & & \\
\hline 58.-Padilla de Duero & & & & & \\
\hline 59.-Torre de Peñafiel & & c & & & \\
\hline 60.-Cuellar & & & & & \\
\hline 61.-Coca & & & & & \\
\hline 62.-Matapozuelos & & & & & \\
\hline 63.-Salamanca & & & & & \\
\hline
\end{tabular}

Tabla 1.- Relación y cronología estimada de los núcleos de población de la Segunda Edad del Hierro en la cuenca sedimentaria del Duero (La numeración corresponde a la del mapa de la fig. 1).

anterior en un momento en el que aún no se reconoce la cultura material "celtibérica" -con un elemento como la característica cerámica a torno-, pero en el que la complejo arqueológico soteño estaba perdiendo sus señas de identidad y empezaban a aceptarse elementos foráneos, como las cerámicas decoradas con peine inciso (que con anterioridad eran mucho más escasas y ahora conocen un desarrollo local, con motivos decorativos de peine impreso) y algunos vasos torneados pintados con bandas vinosas, de procedencia ibérica que venían teniendo éxito al sur del Duero desde, al menos, el siglo VI a.C. (Sacristán 1997: 60-61 y 2007: 35). En cuanto a Padilla, al parecer una de las escasas ciudades nuevas, debió de fundarse a principios del siglo IV a.C. como apunta la cronología de las primeras tumbas de la necrópolis con puñales de la fase formativa del modelo Miraveche-Monte Bernorio (Sanz 1997:430431; ibidem 1990). Y éste podría ser también el caso de Palenzuela.

El lapso transcurrido, dentro del siglo IV, entre este inicio de la concentración urbana y la implantación posterior y muy rápida del torno (como signo visible de la nueva cultura material "celtibérica") puede explicar algunos aspectos importantes de la naturaleza de la evolución que tuvo lugar y me permite corregir y matizar lo expresado por mí con anterioridad sobre el tránsito del Soto a lo celtibérico.
En algunos trabajos he interpretado esta etapa de cambio más como un momento final del mundo del Soto que como un principio de la celtiberización, al identificar ésta, de modo simple, con la implantación de las producciones torneadas características de la nueva etapa, que es un fenómeno posterior y muy rápido, como he dicho ${ }^{6}$.

Una revisión del proceso me inclina ahora a pensar que tales cambios previos a la implantación del torno sí pueden ser considerados como la base del nuevo periodo; un principio, además de un final. La elaboración de vasos torneados sólo tuvo éxito tras asentarse otros cambios previos y profundos y sólo allí donde éstos tuvieron lugar. La concentración urbana fue una de las transformaciones más visibles, pero ella misma se fundamenta en innovaciones técnicas, que dieron lugar a un incremento de la productividad y a un desarrollo económico. Debió de ser en el ambiente de apertura que se pone de manifiesto en la importación de vasos ibéricos y de las producciones decoradas a peine (que venían teniendo éxito al sur del Duero, pero que hasta ese momento no habían calado en el cerrado ámbito soteño), cuando se incorporó un elemento capital que pudo ser la base del proceso: la reja de arado de hierro, unida a la generalización de los útiles de este metal (sobre estos aperos, véase Barril 1999). 
Este ambiente innovador es el que se reflejaría también en las necrópolis de diversos ámbitos de la periferia de la Meseta, con una renovación de los ajuares y creación de nuevos tipos metálicos, como las llamativas producciones broncistas de la Bureba. El crecimiento económico, y tal vez el demográfico (las antiguas aldeas no parecen suficientes para dar cuenta de la escala que llegaron a adquirir las ciudades resultantes), se unirían a las nuevas estrategias de producción para desencadenar el cambio en el sistema de poblamiento y el desarrollo de los núcleos de carácter urbano con la nueva estructura social que comportan. Surgirían también las élites capaces de dirigir y orientar todo el proceso.

Fue sólo tras constituirse este marco urbano cuando se hizo posible la implantación de determinadas técnicas, como el torno de alfarero, que curiosamente parecen haber sido muy exigentes en este sentido, pues no llegaron a asentarse en las áreas donde no se desarrolló el proceso de urbanización, como ocurrió al oeste del Esla y al norte de las tierras sedimentarias, en las Loras burgalesas, donde se aprecian fronteras culturales muy nítidas (Sacristán 2007: 38-39). Ello podría explicarse porque la alfarería "celtibérica" tuvo, como hemos visto, un carácter semiindustrial y precisó una amplitud de mercado que sólo se aseguró con el desarrollo urbano.

Lo anterior explica el surgimiento de la ciudad, pero no, o al menos no totalmente, el particular modelo de ciudades-isla del interior de la meseta. Tras el análisis efectuado, entiendo que no es necesario suponer, como lo hice en su día, ningún rasgo social específico de las etnias implicadas que propiciara la congregación en grandes núcleos (Sacristán 1995); y, en cuanto al crecimiento económico, fue el motor de la urbanización, y no tanto de la forma que la misma adoptó. El resultado final parece que se debió, además, a una combinación de los siguientes factores que ya conocemos: $1^{\circ}$ ) un medio geográfico con espaciosas vegas, que permitió, a partir de un determinado nivel técnico, el mantenimiento autosuficiente de grandes aglomeraciones de varios miles de personas en el propio Territorio de Producción, sin aldeas tributarias; $2^{\circ}$ ) una densidad de población por debajo de la capacidad de carga no sólo del conjunto regional, sino también del espacio propio de cada ciudad, lo que hizo posible ocupar selectivamente sólo las mejores tierras, junto a las que se asentaron las ciudades (con algún matiz en la Tierra de Campos); $3^{\circ}$ ) la formación, como consecuencia del crecimiento económico, de la jerarquía social y de una autoridad que actuó como fuerza centrípeta impulsando y dirigiendo la concentración en algunos de los antiguos poblados.

En otras áreas de la Meseta, estuvo también presente el crecimiento económico y el proceso de urbanización dirigido por una autoridad, pero faltaban espacios con el potencial necesario para sustentar comunidades autosuficientes, y la presión demográfica, en relación con la capacidad de carga del medio, obligó a explotar en mayor medida que en el Duero Medio los recursos del conjunto del territorio, dando lugar a la proliferación de enclaves subsidiarios. Curiosamente, un proceso que recuerda a grandes rasgos al del interior meseteño, aunque con características menos marcadas, se desarrolló en el alto Guadalquivir durante el siglo V a.C., aunque sobre una base de partida muy diferente, cuando grupos aristocráticos potenciaron la nuclearización del territorio concentrando la población de los pequeños asentamientos anteriores en múltiples oppida, en detrimento de los anteriores principados orientalizantes o jefaturas de amplia base territorial que habían surgido en la periferia de Tartessos (Ruiz y Molinos 1992: 258-264) (Fig. 11).

Otra cuestión añadida es si la concentración urbana llevó ya aparejado el desarrollado urbanismo que se manifiesta en las fotografías aéreas. No se puede dar una respuesta en tanto no se hagan las oportunas comprobaciones arqueológicas en puntos estratégicos de la trama urbana entrevista en algunas ciudades. De todos modos, queda claro, por los ejemplos de Valoria y Palenzuela, que las tramas regulares se desarrollaron con anterioridad a las guerras sertorianas, cuando tales ciudades desaparecieron, sin haber estado sometidas antes al dominio romano. Es más, merece considerarse la hipótesis de que tal urbanismo se originó y se desarrolló con la propia formación de la ciudad en el siglo IV a.C., pues éste es el mo- 


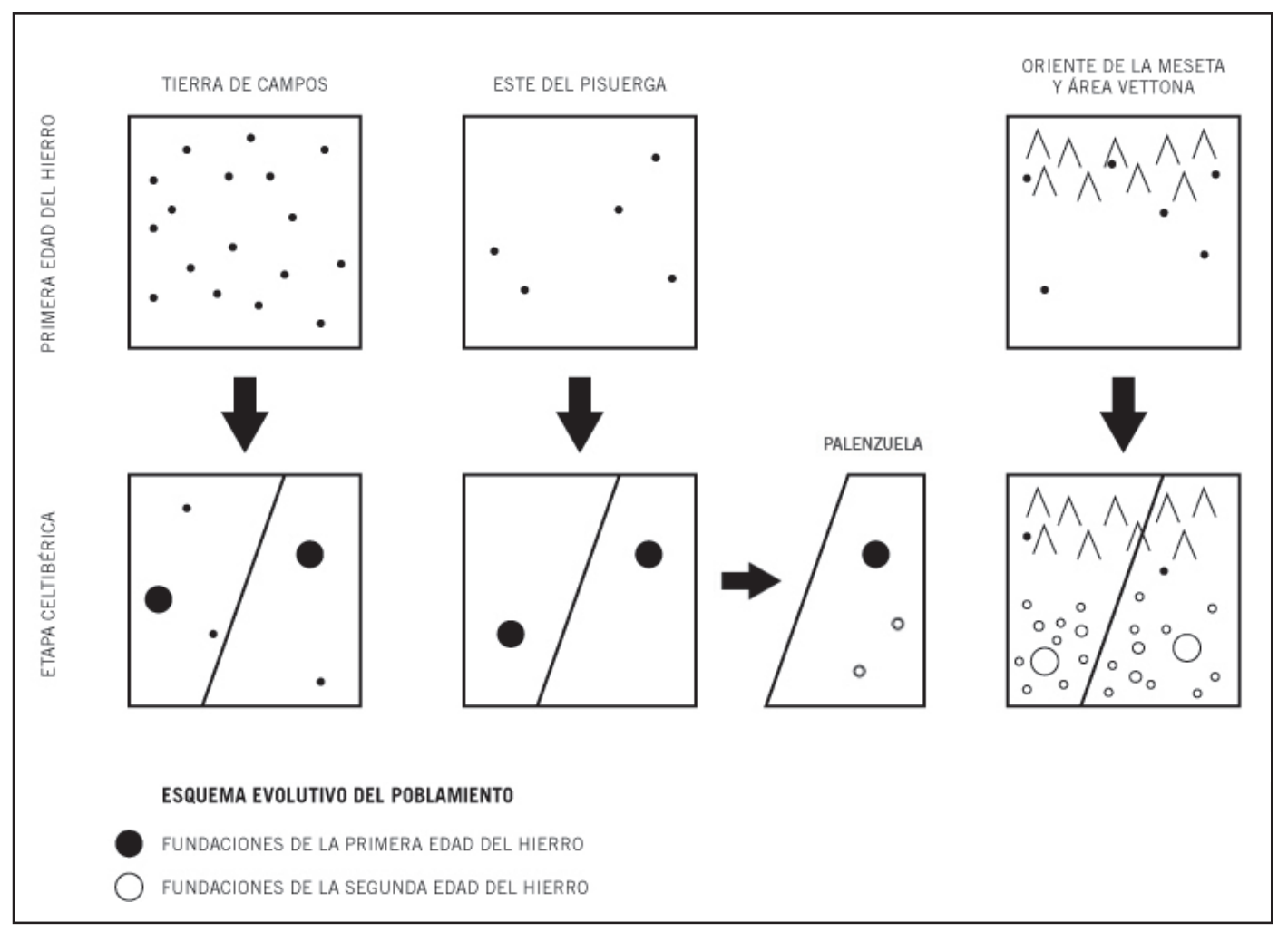

Figura 11.- Esquema de evolución del poblamiento en la cuenca sedimentaria de la Meseta al oeste y al este del Pisuerga, y comparación con otras áreas limítrofes.

mento histórico más propicio, cuando, para albergar a las poblaciones desplazadas y como fruto de un designio dirigido, hubo que ampliar el recinto residencial, que probablemente se delimitaría entonces con un nuevo cercado. No es de extrañar que en tal circunstancia se produjera la planificación urbana bajo la misma dirección autoritaria. La arqueología no desmiente esta idea, pues no muestra cambios en los sistemas constructivos a lo largo de toda la etapa "celtibérica" y, allí donde hay superposiciones de viviendas, parece habitual la continuidad de orientación; así ocurre, por ejemplo, en Cauca, desde los inicios del siglo III a.C. hasta el cambio de era, en una sucesión de cinco fases (Pérez y Blanco 2000: 43).

¿Se podría hablar de una génesis de la ciudad y de un urbanismo de influencia ibérica? Es muy posible que las raíces últimas, como ocurre con otros rasgos culturales, estuvieran en la periferia mediterránea o meridional, pero no deja de llamar la atención, frente a los tó- picos habituales hace algunos años -cuando, por ejemplo, se explicaba el colectivismo vacceo invocando el primitivismo y una sedentarización imperfecta-, que la urbanización de la Meseta cristalizara tempranamente en unos productos tan señeros y alcanzara un éxito tan general y tan sólido que resultan insólitos en el contexto peninsular, y si a tal urbanización fuera asociado el urbanismo planificado sólo podría establecerse el parangón con algunos asentamientos de colonización griegos o fenicio-púnicos.

Esta sorprendente realidad parece reflejarse, incluso, en las Fuentes, que entre las primeras citas de "ciudades" peninsulares mencionan, como recuerda Burillo (2007: 269) algunas de los vacceos, cuando, con motivo de la expedición de Aníbal hasta el territorio de este pueblo, destacan a Helmantica, entonces considerada vaccea, como "gran ciudad de Iberia" (Polieno, 7, 48) o "de Hispania" (Plutarco, Virt. Mul., 248 e), y a Arbucala por su 
magnitud y el número de sus habitantes (Polibio, 3,13,5) (ver también Livio, 21,5,2, que menciona a ambas como ciudades vacceas). La arqueología permite comprobar que el primitivo poblado de Salamanca se extendió desde el cerro de San Vicente al Teso de las Catedrales al menos desde finales del siglo IV o principios del III a.C. (Martín Valls et al. 1991: 153; Benet y Sánchez 1999: 122-123).

\subsection{La edad dorada}

El complejo cultural "celtibérico" del interior de la meseta, incluyendo el modelo territorial forjado durante el siglo IV, estaba ya básicamente configurado al iniciarse el siglo III a.C. El sistema se hizo entonces estable y conoció una era de sólido equilibrio. Es la llamada etapa celtibérica clásica o plena (que no se corresponde con la que recibe este nombre en la Celtiberia histórica -lo que induce a confusión-, sino que se asocia a los típicos conjuntos materiales, especialmente las cerámicas, que abarcan desde el inicio del torno hasta la guerra de Sertorio). Durante estos dos siglos largos, sólo se produjeron algunos cambios de detalle en el poblamiento, como la fundación de dos núcleos menores, Tabanera y Valdecañas, seguramente dependientes de Pallantia (Palenzuela).

Si no conociéramos la historia, se podría hablar de una pax celtiberica, de una etapa de feliz devenir, pero los relatos que iluminan entonces por primera vez la vida regional descubren que durante la segunda mitad de este periodo de prosperidad los pueblos del interior de la Meseta, aunque en menor medida que sus vecinos orientales de la Celtiberia histórica, se vieron sometidos por el expansionismo romano a una dura prueba que aguantaron con firmeza. Ante la presión exterior, la identidad cultural permaneció íntegra, sin señales de quebranto, incluso en las ciudades arévacas del sector oriental del ámbito de estudio, que debieron de ser incorporadas al dominio romano tras la caída de Numancia. Una de ellas, Clunia, emitiría denarios bajo tal dominio desde aproximadamente el año 100 a.C., y un molde monetal de Pinilla Trasmonte ha inducido la sospecha de que también allí funcionara una ceca (¿tal vez la que emitió con el letrero de Sekobirikes?) que, a juzgar por la dispersión de su numerario, podría localizarse por este sector (García-Bellido 1974; Villaronga 1978). En el resto del territorio no se acuñó moneda -aunque sí se atesoró-, porque debió de permanecer independiente hasta el desenlace de las guerras de Sertorio y Pompeyo.

\subsection{Del filtro pompeyano a la romaniza- ción: la etapa tardoceltibérica}

El final de este periodo de plenitud de la cultura indígena no se produjo por decadencia, ni por incapacidad de adaptación, ni por haber sobrepasado la capacidad de carga del sistema, ni siquiera por asfixia provocada por una pertinaz presión exterior, que el sistema demostró poder aguantar, sino por pura y brutal destrucción. El acontecimiento crucial que vino a interferir traumáticamente en un proceso que había estado mediatizado desde un siglo antes por los ejércitos romanos, fue la guerra civil romana en la que Sertorio utilizó y lideró la resistencia indígena frente al imperialismo de la Roma oficial representado por Pompeyo. La guerra fue cruel por ambos bandos, pero las consecuencias para los perdedores, entre los que estaban las ciudades del territorio que estudiamos, entre las que Clunia tuvo un papel protagonista sirviendo de refugio temporal a Sertorio, fueron catastróficas. Las Fuentes narran cómo las tropas de Pompeyo incendiaron y saquearon sistemáticamene las poblaciones, y lo confirma la arqueología a través de los niveles generalizados de incendio y de las ocultaciones de joyas y denarios atestiguados en la región y atribuibles a estos años (Salamanca, Padilla, Palenzuela, Palencia, Roa...).

Las destrucciones de Pompeyo actuaron como un gigantesco filtro. Allí terminó la soberanía para los pueblos que aún la conservaban. Y allí, como se refleja en la tabla $n^{\circ} 1$, se cortó en seco la vida de muchas de las prósperas ciudades que habían iniciado su existencia en la prehistoria soteña. De los más de 60 núcleos del momento clásico, sólo menos de la mitad sobrevivieron y consiguieron rehacerse, a veces con gran dificultad. 


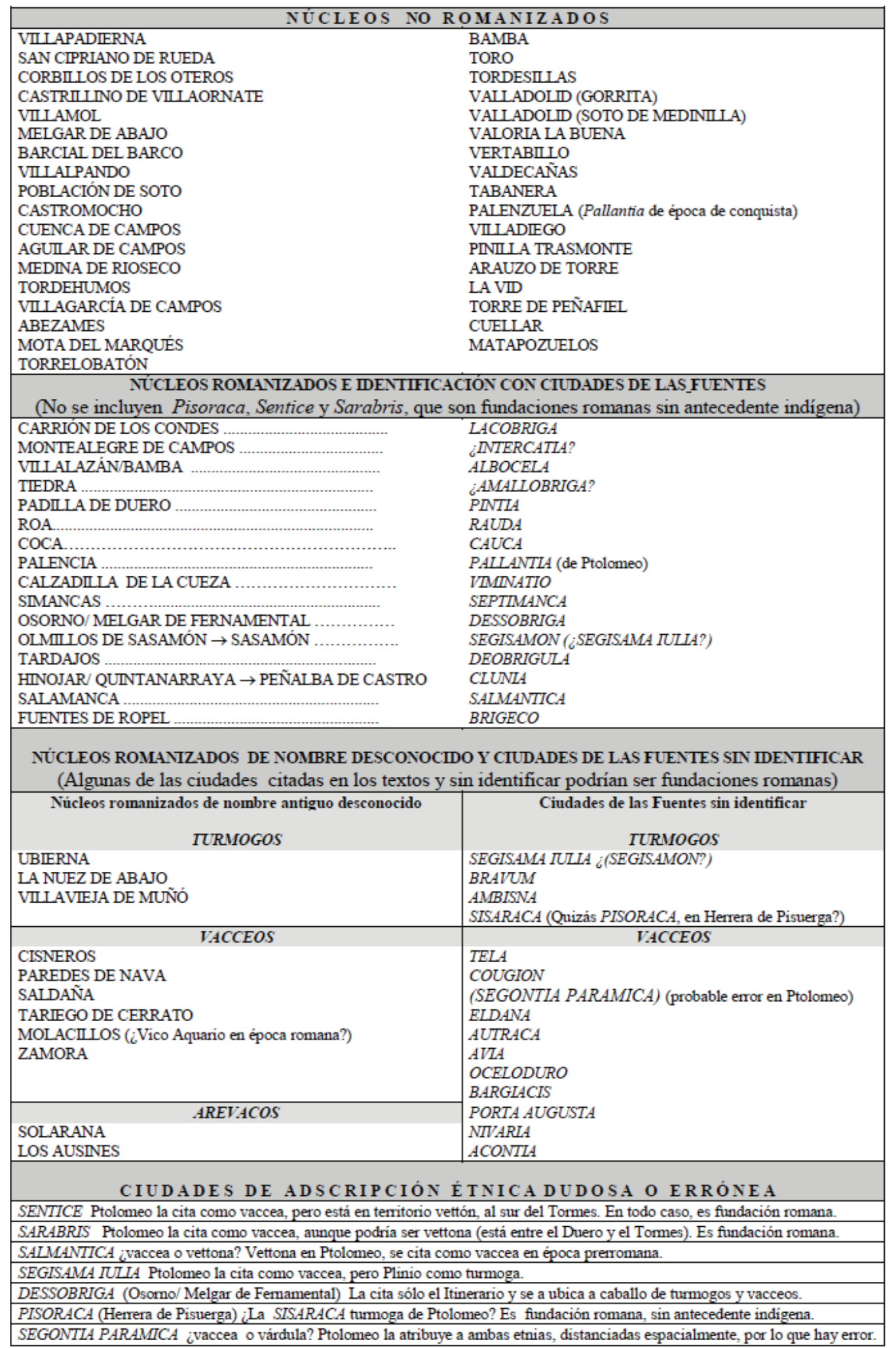

Tabla 2.- Relación de yacimientos no romanizados, romanizados y ciudades citadas en los textos clásicos en el área de estudio, con las correspondencias conocidas. 
El filtro pompeyano no pudo sofocar el autonomismo indígena, que se mantuvo latente y dio todavía lugar a algunos episodios de rebeldía, primero en los años 56-55 a.C., con protagonismo de las ciudades vacceas, y más tarde en el 29 a.C., cuando de nuevo los vacceos, por instigación de los treviros de la Galia, se levantaron junto con astures y cántabros, en lo que parece un anuncio de las guerras cántabras. Durante este tiempo, las señas de identidad siguieron reconocibles en casi todos los aspectos, en tanto la romanización efectiva, más allá del puro dominio político, era todavía anecdótica. Pero sí se vieron afectadas las tradiciones técnicas y estéticas. En la alfarería, se inauguraron otras producciones claramente vinculadas a las anteriores, aunque con tipos y decoraciones característicos que revelan una reconversión del sistema productivo y que definen un nuevo estilo que sirve, a su vez, como marcador de la nueva etapa tardoceltibérica (Sacristán 1986: 221245 y 1986-1987).

El éxito de la romanización sobre el complejo cultural indígena no resulta especialmente visible hasta el siglo I d.C., y probablemente fue fruto de las reformas administrativas que desde época de Augusto aceleraron la incorporación de las tierras interiores de la Meseta a los circuitos económicos del Imperio.

En lo que se refiere al poblamiento, el nuevo marco administrativo aprovechó y potenció la red urbana heredada, a la que apenas se incorporó alguna ciudad de nueva fundación, si bien entre los nodos urbanos proliferaron múltiples explotaciones agrarias, las villae, exponentes de un nuevo modo de producción.

Como signo de lo anterior, resulta llamativa, como se indicó más arriba, la concordancia de la imagen conocida por la arqueología con la transmitida por los documentos de época imperial. El número de núcleos citados por diversos textos clásicos en el territorio que nos ocupa no alcanza la treintena, veinticuatro de ellos mencionados por Ptolomeo y el resto (Amallobriga, Septimanca, Nivaria, Dessobriga y Acontia) por otros documentos. Exceptuando algunos que podrían ser mansiones itinerarias sin carácter urbano, o la fundación romana de Pisoraca, en su mayoría son herederos de las ciudades indígenas y aso- ciables a una civitas. En una correspondencia casi exacta, conocemos por la arqueología 28 núcleos indígenas romanizados, 16 de ellos ya identificados con ciudades de las Fuentes clásicas. Igualmente concuerda con este cuadro el transmitido por Plinio, que asigna 17 civitates a los vacceos y 4 a los turmogos, lo que, sumando la arévaca Clunia, la astur Brigeco y la vettona Salmantica da un total de 24 civitates en el territorio que consideramos.

Aunque en un marco social y político muy distinto, la malla urbana de época imperial fosiliza, pues, la situación anterior. Las ciudades regionales son las mismas ciudades indígenas que pasaron el tamiz pompeyano, con el añadido de Pisoraca (Herrera de Pisuerga) y con algunos cambios de emplazamiento, como Clunia, que se traslada a la amplia plataforma del Alto de Castro con un urbanismo plenamente romano, al asumir un importante papel administrativo, en especial a raíz de su conversión en capital de un Convento Jurídico; o Segisamon (Sasamón), que a partir del campamento de Augusto se transformó igualmente en una ciudad romana. También se refundan en otro emplazamiento, siempre en el fondo de valle, núcleos como Dessobriga (Tardajos), Ubierna o la Pallantia de Palencia.

Faltan excavaciones extensas que revelen el nuevo marco urbanístico en los antiguos asentamientos. No obstante, hay indicios de que se respetó en muchos casos el trazado anterior (por ejemplo en Viminatio y Amallobri$g a$ ), a veces con remodelaciones parciales de cierta importancia, como lo insinúa la regularidad de las insulae en un sector de Pintia; $\mathrm{y}$, por otra parte, aparecen aquí y allá, intramuros y extramuros, grandes domi como las que se perciben en la fotografía aérea en la misma Pintia, en Amallobriga y en Brigeco, o como lo demuestran las excavaciones todavía inéditas de Montealegre. Por supuesto, se producen cambios en los sistemas constructivos, con utilización habitual de piedra en los cimientos, frente a la práctica exclusividad anterior del adobe, y la normalización de los materiales cerámicos, sobre todo la teja, aunque el alzado de los muros siguiera siendo habitualmente de adobe.

Como expresión de la fuerza del sustrato prerromano, en estas ciudades, junto a los 
nuevos elementos de cultura material propia de un ambiente intensamente romanizado, subsistía todavía el gusto por las propias tradiciones técnicas, y, así, junto a las terra sigillata convivieron en abundancia los vasos del estilo tardoceltibérico iniciado tras la guerra de Sertorio, con la incorporación de algunas nuevas producciones, como las clunienses, nacidas de la misma raíz estética.

El silencio sobre su situación jurídica permite suponer que la mayoría de estas ciudades fueron dediticias, si bien algunas se vieron favorecidas por el estatuto municipal, como parece ser el caso de Cauca, por no hablar del estatuto colonial de Clunia. Si a este panorama, que se prolongó hasta la crisis del siglo III, se suma la amplia perduración de la onomástica y de instituciones como el hospicio "indígena", tendremos una muestra palpable de la inesperada vitalidad de un complejo cultural decapitado más de medio siglo antes del inicio del Imperio. No obstante, la larga y profunda corriente cultural que había sido frenada en el filtro pompeyano, y posteriormente domesticada, terminó disolviéndose en el seno de un proyecto más fuerte.

\section{Reflexiones finales}

La cuenca sedimentaria del Duero conoció durante los últimos siglos del primer milenio a.C. una intensa urbanización, que tuvo su origen con anterioridad a la influencia romana, durante el siglo IV a.C., en un momento de apertura y renovación tecnológica de los poblados del Soto. El aumento de la producción fue propiciado sobre todo por el arado de reja de hierro e hizo posibles las aglomeraciones de carácter urbano, en un proceso de sinecismo forzado por una autoridad surgida y vigorizada en el mismo proceso. El resultado fue la concentración de la población en ciudades grandes -en el contexto peninsular de la época-, distantes entre sí, ubicadas en los espacios más productivos del territorio y organizadas como estados independientes.

El análisis sugiere que esta forma de poblamiento responde a una baja densidad de población en el conjunto del territorio, por debajo de su capacidad de carga. El mode- lo de ciudades aisladas sin aldeas tributarias impone también un límite máximo para el número de habitantes de cada ciudad, entre 5.000 y 10.000 , a partir del cual habría sido preciso fundar otros núcleos secundarios, lo que al parecer no ocurrió sino excepcionalmente.

Estas limitaciones de tamaño implican a su vez límites de concentración de riqueza y de poder y pueden explicar otros aspectos llamativos como la ausencia de monumentalidad: el por qué las ciudades del Duero medio, como en general las del interior de la Península por parecidas razones de escala de la civitas, no tuvieron palacios ni templos suntuarios. A su vez, como consecuencia del aislamiento y de la falta de presión demográfica y económica tampoco hubo una presión para la formación de estados que englobaran varias ciudades.

Las ciudades de la cuenca media del Duero tuvieron un urbanismo planificado y ordenado, pero, como acabamos de decir, de sencilla arquitectura de adobe. Su aspecto rústico y su economía agrícola-ganadera pueden inducir a asimilarlas engañosamente con las aglomeraciones rurales de la Castilla preindustrial. La repoblación de algunos de aquellos centros en la etapa altomedieval con su antiguo nombre (Salamanca, Palencia, Simancas, Roa, Coca, etc.) puede afianzar el espejismo y servir de base a una reivindicación de presuntos orígenes del presente, tanto más cuando se trata de un momento brillante de la historia meseteña, que suministra notables episodios de resistencia frente a Roma. Tal perspectiva es espuria. El estudio de la protohistoria debe descontaminarse del actualismo, que ha sido certeramente criticado como "una relación incestuosa de familiaridad" (Hill y Cumberpatch 1993: 129) y de la utilización identitaria. Aquellas comunidades perdidas en un rincón del orbe (como veía Cicerón a los vacceos - pro $\mathrm{Cn}$. Plancio, 84-) fueron, pese a su apariencia, organismos políticos independientes y boyantes que desarrollaron una fórmula original, estable y altamente eficiente de organización como respuesta singular a un determinado medio geográfico. Por todo ello, constituyen ejemplos de la variabilidad y de la creatividad humana que, sin necesidad de otros aditamentos, son universalmente instructivos. 


\section{Notas}

1 Debido al retraso de varios años sobre las fechas inicialmente previstas para esta publicación, una parte de este trabajo ha visto ya la luz (Sacristán 2010) en la obra colectiva De la región vaccea a la arqueología vaccea (Sanz, Romero y de Pablo, eds.). Las páginas que siguen son una versión corregida, actualizada y aumentada.

${ }^{2}$ En el análisis territorial he prescindido de los poblados cuya vida se truncó en momentos tempranos de la etapa celtibérica clásica a la que luego nos referiremos, justo cuando se empezaban a producir los primeros vasos torneados "celtibéricos", incluido alguno de vida muy corta, como el de Olivares de Duero, que había sido fundado poco tiempo antes.

3 No contabilizo Segontia Paramica, que casi con seguridad es un error de Ptolomeo, ni Sentica y Sarabris, que Ptolomeo menciona también como vacceas, pero que, además de quedar fuera del territorio que estudiamos, serían más bien vettonas y casi con seguridad fueron fundaciones romanas, como lo fue Pisoraca/Sisaraca y tal vez lo fuera también alguna otra de las no identificadas. Más adelante se incluye una relación de las ciudades citadas en los textos de época romana.

4 Para una discusión sobre los significados e interpretaciones de los términos Celtiberia y celtíberos, véase, en especial, Burillo, 2008.

5 Diamond 1998: 331-334. En su aplicación específica a la civitas, véase, en este mismo sentido, Ortega (1999: 443). Ruiz y Molinos (1992: 258-271) han resaltado también el papel de las aristocracias en el surgimiento de los oppida ibéricos, como lo ha hecho Collis (1989) en relación con los europeos.

${ }^{6}$ Sobre esto, mantengo mi discrepancia con quienes han supuesto que la producción de vasos torneados se desarrolló gradualmente a partir y por imitación de las primeras importaciones ibéricas a que me he referido. No encuentro evidencias en tal sentido; el éxito del torno parece un fenómeno independiente de aquellas importaciones y se traduce en la implantación rápida de unas nuevas producciones muy estandarizadas técnica y formalmente.

\section{ReFERENCIAS BIBLIOGRÁFICAS}

Abarquero, J. F.; Palomino, A. L. (2006): Vertavillo. Primeras excavaciones arqueológicas en un 'oppidum vacceo’ del Cerrato palentino. Publicaciones de la Institución Tello Téllez de Meneses, nº 77: 31-116.

AвÁsolo, J. A. (1978): Carta arqueológica de la provincia de Burgos. Partidos judiciales de Castrojeriz y Villadiego. Burgos.

Abásolo, J. A.; Ruiz Vélez; I. y Pérez Rodríguez, F. (1983): Castrojeriz, I. El vertedero de la Colegiata. Noticiario Arqueológico Hispánico, 17: 193-318.

Almagro-Gorbea, M. (1993): Los Celtas en la Península Ibérica: origen y personalidad cultural. Los Celtas: Hispania y Europa (M. Almagro Gorbea, dir.), Actas, San Lorenzo del Escorial, Madrid: 121-173.

Álvarez-Sanchís, J. R. (1999): Los Vettones. Bibliotheca Archaeologica Hispana, 1, Real Academia de la Historia, Madrid.

Aratikos arqueólogos S. L. (2007): Excavación arqueológica en la plaza de la Alhóndiga no 3. Roa (Burgos). Informe técnico inédito, Servicio Territorial de Cultura de Burgos.

BARril Vicente, M. (1992): Instrumentos de hierro procedentes de la provincia de Soria en el Museo Arqueológico Nacional. Boletín del Museo Arqueológico Nacional, X: 5-20.

Barril Vicente, M. (1999): Arados prerromanos de la Península Ibérica: las rejas y su distribución zonal en el interior peninsular. En F. Burillo (coord.) 1999: 89-101.

Barrio Martín, J. (1988): Las cerámicas de la necrópolis de Las Erijuelas, Cuellar (Segovia). Estudio de sus producciones cerámicas en el marco de la Segunda Edad del Hierro en la Meseta Norte. Diputación provincial de Segovia, Segovia.

Barrio Martín, J. (1999a): La II Edad del Hierro en Segovia (España). Estudio arqueológico del territorio y la cultura material de los pueblos prerromanos. BAR International Series, 790, Oxford.

BARrio MARTín, J. (1999b): La temprana metalurgia del hierro en la Sierra de Ayllón a partir de los elementos férreos de la necrópolis de la Dehesa (Ayllón, Segovia). En F. Burillo (coord.) 1999: 181-193.

Beltrán Lloris, F. (1988): Un espejismo historiográfico. Las organizaciones gentilicias hispanas. Actas I Congreso Peninsular de Historia Antigua, Santiago de Compostela: 197-237. 
Benet, N. y SÁnchez Guinaldo, A. I. (1999): Urbanismo medieval de Salamanca: ¿continuidad o reconstrucción? Actas III Curso sobre la Península Ibérica y el Mediterráneo entre los siglos XI y XII (28-31 de julio de 1998), Codex Aquilarensis, 15, Aguilar de Campoo: 120-152.

Blanco García, J. F. (1993): La cerámica celtibérica gris estampillada en el centro de la Cuenca del Duero. Las producciones de Coca (Segovia). Boletín del Seminario de Arte y Arqueología, LIX, Valladolid: 113-139.

Blanco García, J. F. (1994): El Castro protohistórico de la Cuesta del Mercado (Coca, Segovia). Cuadernos de Prehistoria y Arqueología Universidad Autónoma de Madrid, 21: 35-80.

Blanco García, J. F. (1998): Las producciones cerámicas del alfar vacceo de Cauca (Coca, Segovia). Madrider Mitteilungen, 39: 121-141.

Blanco García, J. F. (2001): La cerámica celtibérica gris de imitación de vasos metálicos en el valle del Duero: propuesta de sistematización y problemática en torno a su origen. Cuadernos de Prehistoria y Arqueología Universidad Autónoma de Madrid, 27: 23-62.

Burillo Mozota, F. (coord.) (1990): II Simposio sobre los celtíberos: Necrópolis celtibéricas (Daroca, 1988). Institución Fernando El Católico, Zaragoza.

Burillo Mozota, F. (1995): Conclusiones y comentarios. En F. Burillo (coord.) 1995: 547-562.

Burillo, F. (coord.) (1995): III Simposio sobre los celtíberos: Poblamiento Celtibérico (Daroca, 1991). Institución Fernando El Católico Zaragoza.

Burillo, F. (coord.) (1999): IV Simposio sobre los Celtíberos: Economía (25-27 de septiembre de 1997). Institución Fernando El Católico. Zaragoza.

Burillo, F. (2007): Los Celtíberos. Etnias y estados. Edición actualizada, Crítica, Barcelona.

CAlonge, G. (1995): Interpretación de los resultados de las investigaciones medioambientales y arqueológicas y su relación con el pretérito espacio físico vacceo del valle medio del Duero. En G. Delibes et al. (eds.) 1995: 529-539.

Capalvo, A. (1986): El léxico pliniano sobre Hispania: etnonimia y designación de asentamientos urbanos. Caesaraugusta, 66: 49-68.

Castro García, L. De; Blanco, R. (1975): El castro de Tariego de Cerrato (Palencia). Publicaciones de la Institución Tello Téllez de Meneses, 35, Palencia: 55-138.

Celis, J. (1996): Origen, desarrollo y cambio en la Edad del Hierro de las tierras leonesas. Historia de León a través de la arqueología, Actas Arqueoleón 1993-1994, León: 41-67.

Celis, J. (2007): En los límites noroccidentales del territorio vacceo. En C. Sanz y F. Romero (eds.) 2007: 43-58.

Centeno, I.; Sanz Mínguez, C.; Velasco, J.; Garrido, A.I. (2003): Aproximación al urbanismo vacceoromano de Pintia. En C. Sanz Mínguez y J. Velasco (eds.) 2003: 69-98.

Cerdeño, M.L.; San Martí, E.; García Huerta, R. (1999): Las relaciones comerciales de los celtíberos. En F. Burillo (coord.) 1999: 263-299.

Checa, A.; Jimeno, A.; Juan Tresserras, J.; Benito, J.P.; Sanz, A. (1999): Molienda y economía doméstica en Numancia. En F. Burillo (coord.) 1999: 63-68.

Collis, J. (1989): La Edad del Hierro en Europa. Labor, Madrid.

Cuadrado, A.; San Miguel, L. C. (1993): El urbanismo y la estratigrafía del yacimiento vacceo de Melgar de Abajo (Valladolid). En F. Romero, C. Sanz y Z. Escudero (eds.) 1993: 303-334.

Cubero, C. (1999): Agricultura y recolección en el área celtibérica a partir de datos paleocarpológicos. En F. Burillo (coord.) 1999: 47-61.

Delibes, G.; Esparza, A.; Martín Valls, R.; Sanz Mínguez, C. (1993): Tesoros celtibéricos de Padilla de Duero. En F. Romero, C. Sanz y Z. Escudero (eds.) 1993: 397-470.

Delibes, G.; Esparza, A.; Martín Valls, R. (1996): Los tesoros prerromanos de Arrabalde (Zamora) y la joyería celtibérica. Zamora.

Delibes, G.; Romero, F.; Morales, A. (eds.) (1995): Arqueología y medio ambiente. El primer milenio a.C. en el Duero Medio. Junta de Castilla y León, Valladolid. 
Delibes, G.; ViñÉ, A.; SAlvador, M. (1998): Santiuste, una factoría salinera de los inicios de la Edad del Bronce en Otero de Sariegos (Zamora). Minerales y metales en la Prehistoria Reciente (G. Delibes, ed.), Studia Archaeologica, 88, Valladolid: 155-198.

Diamond, J. (1998): Armas, gérmenes y acero. Debate, Madrid.

Escudero, Z. (1999): Datos sobre la cerámica común a torno de época Vaccea. II Congreso de Arqueología Peninsular (Zamora, 1996), Tomo III, Primer milenio y metodología, Madrid: 275-288.

Escudero, Z. (1995): Nuevos estudios sobre el poblado vacceo de 'El Soto de Medinilla' (Valladolid). En G. Delibes, F. Romero y A. Morales (eds.) 1995: 179-217.

Escudero, Z.; SAnZ, C. (1993): Un centro alfarero de época vaccea: el horno 2 de Carralaceña (Padilla/Pesquera de Duero, Valladolid). En F. Romero, C. Sanz y Z. Escudero (eds.) 1993: 471-492.

Esparza Arroyo, A. (1999): Economía de la Meseta prerromana. Studia Historica, Ha Antigua, 17: 87-123.

Fernández Jiménez, J. M.; Marcos, G. J.; Misiego, J. C. (1995): Una tumba de incineración de la necrópolis de La Vega (Venta de Baños, Palencia). Actas del III Congreso de Historia de Palencia, I, Palencia: 125-152.

FernÁNDeZ-Posse, Ma D. (1998): La investigación protohistórica en la Meseta y Galicia. Síntesis, Madrid.

Galán Domingo, E.; Ruiz-Gálvez, M. (1996): Divisa, dinero y moneda. Aproximación al estudio de los patrones metrológicos prehistóricos peninsulares. Homenaje al Profesor Manuel Fernández-Miranda ( $\mathrm{M}^{\mathrm{a}}$.A. Querol, T. Chapa, eds.), Complutum Extra, 6-II, Madrid: 151-165.

García-Bellido, M. P. (1974): Tesorillo salmantino de denarios ibéricos. Zephyrus, XXV: 379-395.

García-Bellido, M. P. (1999): Sistemas metrológicos, monedas y desarrollo económico. En F. Burillo (coord.) (1999): 363-385.

Gómez Pérez, A.; Sanz Mínguez, C. (1993): El poblado vacceo de Las Quintanas, Padilla de Duero (Valladolid). En F. Romero et al. (eds.) 1993: 335-370.

HagGet, P. (1976): Análisis locacional en Geografia Humana. Gustavo Gili, Barcelona.

Hill, J.D. y CumberPatch, C.G. (1993): Volviendo a pensar la Edad del Hierro. Trabajos de Prehistoria, 50: 127-137.

HERAS FernÁndez, E. (2000): Aproximación a la evolución del poblamiento en el suroeste de la provincia de Soria durante la Edad del Hiero y la etapa altoimperial. Soria Arqueológica, 2, Soria: 205-238.

Hodder, I. (1988): Interpretación en Arqueología. Corrientes actuales. Crítica, Barcelona.

IBÁÑEz GonZÁLEZ, J. (1999): Evolución de la potencialidad agrotérmica en la Celtiberia durante la Edad del Hierro. En F. Burillo (coord.) 1999: 11-46.

Jimeno, A. (1999): Religión y ritual funerario celtibéricos. Celtíberos. Homenaje a José Luis Argente, Revista de Soria, Segunda época, $n^{\circ}$ 25: 5-18.

Jimeno, A. (2000): El origen del urbanismo en el Alto Duero. Soria Arqueológica, 2, Soria: 239-262.

Jimeno, A.; ArLegui, M. (1995): El poblamiento en el Alto Duero. En F. Burillo (coord.) 1995: 93-126.

Jimeno, A.; TABernero, C. (1996): Origen de Numancia y su evolución urbana. Homenaje al Profesor Manuel Fernández-Miranda (Mª.A. Querol, T. Chapa, eds.), Complutum Extra, 6-I, Madrid: 415-432.

Lorrio, A. J. (1997): Los Celtíberos. Complutum Extra 7, Madrid.

Lorrio, A. J.; Gómez Ramos, P.; Montero, I.; Rovira, S. (1999): Minería y metalurgia celtibérica. En F. Burillo (coord.) 1999: 161-180.

Martín Valls, R. (1984): Prehistoria Palentina. Historia de Palencia. I. Edades Antigua y Media (J. González, dir.), Palencia: 169-175.

Martín Valls, R.; Benet, N.; Macarro, C. (1991): Arqueología de Salamanca. Del Paleolítico a la Historia (M. Santonja, coord.), Salamanca: 137-163.

Mayoral, V.; CRespo, M. (2000): Informe arqueológico inédito sobre zanja abierta por la Confederación Hidrográfica del Duero en Las Quintanas de Padilla de Duero. Junta de Castilla y León.

Molinero Pérez, A. (1952): Una necrópolis del Hierro Céltico en Cuellar (Segovia). II Congreso Nacional de Arqueología (Madrid, 1951), Madrid: 337-354. 
Moreda, J.; Nuño, J. (1990): Avance al estudio de la necrópolis de la Edad del Hierro de El Pradillo, Pinilla Trasmonte (Burgos). En F. Burillo (coord.) 1990: 171-181.

Olmo Martín, J. DEL (1996): Arqueología aérea en la Dehesa de Morales. Brigeco, 6: 54-57.

Olmo Martín, J. del (1999): Arqueología Aérea en tres ciudades indígenas romanizadas. Los orígenes de la ciudad en el Noroeste Hispánico. Actas del Congreso Internacional (Lugo, 15-18 de mayo de 1996), Lugo: 409-428.

Olmo Martín, J. Del (2006): Arqueología Aérea de las ciudades romanas de la Meseta Norte. Algunos ejemplos de urbanismo de la primera Edad del Hierro, segunda Edad del Hierro y romanización. Nuevos documentos de ingeniería romana. III Congreso de las Obras Públicas Romanas, Astorga: 313-340.

Olmo Martín, J. Del; San Miguel, L. C. (1993): Arqueología aérea en asentamientos vacceos. En F. Romero, C. Sanz y Z. Escudero (eds.) 1993: 507-528.

OrtegA, J. (1999): Al margen de la identidad cultural: historia social y económica de las comunidades campesinas celtibéricas. En F. Burillo (coord.) 1999: 417-452.

Pérez González, C.; Blanco García, J. F. (2000): Nuevas investigaciones arqueológicas en Cauca. Revista de Arqueología, 228: 38-47

Pérez Rodríguez, F. J.; Abarquero, F. J. (2010): 'La Ciudad' de Paredes de Nava. Civitas vacceorum en Tierra de Campos. Vaccea, 3: 28-36.

Polo, C. (1999): La metalurgia del hierro durante la época celtibérica en Sierra Menera (GuadalajaraTeruel). En F. Burillo (coord.) 1999: 195-199.

Reynolds, P. J. (1988): Arqueología experimental. Una perspectiva de futuro. Eumo, Vic.

Romero, F.; SAnz, C.; Escudero, Z. (eds.) (1993): Arqueología vaccea. Estudios sobre el mundo prerromano en la cuenca media del Duero. Junta de Castilla y León, Valladolid.

Romero, F.; Ramírez, M. L. (1999): Estrategias de subsistencia en la cuenca media del Duero durante la Edad del Hierro. En F. Burillo (coord.) 1999: 453-465.

Romero, F.; Górriz, C. (2007): Actividad textil y evidencias arqueológicas. En C. Sanz Mínguez y F. Romero Carnicero (eds.) 2007: 115-118.

Romero, F. y SAnz Mínguez, C. (2009): Tiempo y género a partir de la Arqueología. La necrópolis de Pintia. Protagonistas del pasado. Las mujeres desde la Prehistoria al siglo XX $\left(\mathrm{M}^{\mathrm{a}} \mathrm{I}\right.$. del Val, C. de la Rosa, $\mathrm{M}^{\mathrm{a}}$ J. Dueñas, M. Santo Tomás, coords.), Valladolid: 59-103.

Romero, F.; Sanz Minguez, C. (eds.) (2010): De la Región Vaccea a la arqueología vaccea. Vaccea Monografías, 4, Valladolid.

Romero, F.; Sanz Mínguez, F.; Górriz, C.; De Pablo, R. (e.p.): Los sistemas defensivos de Pintia. Reunió Internacional. Les defensas exteriors i la poliorcètica prerromana en la Mediterrània Centroocidental: Els Fossats (Lleida, 29-30 de novembre 2010).

Ruiz, A.; Molinos, M. (1992): Los Iberos. Análisis arqueológico de un proceso histórico. Crítica, Barcelona. Sacristán, J. D. (1986): La Edad del Hierro en el valle medio del Duero. Rauda (Roa, Burgos). Valladolid.

SACRISTÁn, J. D. (1986-87): Sobre la formación de los conjuntos cerámicos tardoceltibéricos. Actas del Coloquio Internacional sobre la Edad del Hierro en la Meseta Norte (Salamanca, 1984), Zephyrus, 39-40: 179-184.

SACRISTÁn, J.D. (1989): Vacíos vacceos. III Coloquio Internacional de Arqueología Espacial: Fronteras (Teruel, 1989), Arqueología Espacial, XIII: 77-89.

SACRISTÁn, J. D. (1993): Aspectos industriales de la producción cerámica en época celtibérica. Los dermatoglifos. En F. Romero, C. Sanz y Z. Escudero (eds.) 1993: 493-506.

Sacristán, J. D. (1994): Apuntes sobre la geografía poblacional vaccea. Boletín del Seminario de Arte y Arqueología, LX: 139-152.

SACRISTÁn, J. D. (1995): Reflexiones en torno al modelo de poblamiento de época celtibérica en la cuenca media del Duero. En F. Burillo (coord.) 1995: 369-372.

Sacristán, J. D. (1997): Buscando a los vacceos. En el Iberespacio. Kalathos, 16: 45-71.

SACRISTÀn, J. D. (2007): La Edad del Hierro en la provincia de Burgos. Diputación de Burgos, Burgos. 
SACristán, J. D. (2010): El poblamiento y el urbanismo vacceos. En F. Romero y C. Sanz (eds.) 2010: 123-162. Sacristán, J. D.; Pérez Rodríguez, F. (1986): Un conjunto cerámico tardoceltibérico. Sautuola, V: 81-113.

Sacristán, J. D.; San Miguel, L. C.; Barrio, J.; Celis, J. (1995): El poblamiento de época celtibérica en la cuenca media del Duero. En F. Burillo (coord.) 1995: 337-367.

Sacristán, J. D.; Villalaín, J. D.; García Valdés, L. (1999): Holmes: un proyecto de estudio de improntas humanas antiguas. II Congreso de Arqueología Peninsular (Zamora, 1996), Tomo III, Primer milenio y metodología, Madrid: 683-688.

SAlinas de FríAs, M. (1990): El colectivismo agrario de los vacceos: una revisión crítica. Actas del I Congreso de Historia de Zamora. II: Prehistoria- Mundo Antiguo (Zamora 1988), Zamora: 429-435.

SAlinAS DE FríAs, M. (1997): En torno a viejas cuestiones: guerra, trashumancia y hospitalidad en la Hispania prerromana. Pueblos, lenguas y escrituras en la Hispania prerromana (VII Coloquio sobre Lenguas y Culturas Paleohispánicas, Zaragoza 1997), Zaragoza-Salamanca: 281-293.

SÁnchez Moreno, E. (1998): De ganados, movimientos y contactos. Revisando la cuestión trashumante en la protohistoria hispana: la Meseta occidental. Studia Historica. Historia Antigua, 16: 53-84.

San Miguel Maté, L. C. (1993): El poblamiento de la Edad del Hierro al occidente del valle medio del Duero. En F. Romero, C. Sanz y Z. Escudero (eds.) 1993: 21-65.

SAnZ Mínguez, C. (1990): Metalistería prerromana en la cuenca del Duero. Una propuesta secuencial para los puñales de tipo Monte Bernorio. Boletín del Seminario de Arte y Arqueología, LVI: 172-187.

SAnz Mínguez, C. (1997): Los Vacceos: cultura y ritos funerarios de un pueblo prerromano del valle medio del Duero. La necrópolis de Las Ruedas, Padilla de Duero (Valladolid). Arqueología en Castilla y León, Memorias, 6, Junta de Castilla y León y Ayuntamiento de Peñafiel, Salamanca.

SAnZ, C.; Escudero, Z. (1995): Las estelas del cementerio vacceo de la Ruedas, Padilla de Duero (Valladolid). Actas del V Congreso Internacional de Estelas Funerarias, Soria: 165-177.

Sanz, C.; Velasco, J. (eds.) (2003). Pintia. Un oppidum en los confines orientales de la región vaccea. Investigaciones Arqueológicas Vacceas, Romanas y Visigodas (1999-2003). Catálogo de la Exposición (Valladolid, 2003), Universidad de Valladolid.

Sanz, C.; Velasco, J.; Centeno, I.; Gallardo, Ma A.; del Olmo, J. (2003): Pintia: Nacimiento y desarrollo de un oppidum vacceo-romano. En C. Sanz y Velasco (eds.) 2003: 45-65.

Sanz, C.; Romero, F.; Velasco, J.; Centeno, I. (2003): Nuevos testimonios sobre la agricultura vaccea. En C. Sanz y Velasco (eds.) 2003: 99-123.

Sanz, C.; Romero, F. (eds.) (2007): En los extremos de la Región Vaccea. Catálogo de la Exposición (Cea/ León y Padilla de Duero/Valladolid), Caja España, León.

Sanz, C.; Romero, F. (2007) Pintia, un oppidum en el extremo oriental de la Región Vaccea. En C. Sanz y Romero (eds.) 2007: 59-77.

SAnZ, C.; Romero, F.; Górriz, C. (2007): Espacios domésticos y áreas funcionales en los niveles sertorianos de la ciudad vacceo-romana de Pintia (Padilla de Duero / Peñafiel, Valladolid). L'espai domèstic $i$ l'organització de la societat a la protohistòria de la Mediterrània occidental (Ier mil-lenni aC), Actes de la IV Reunió Internacional d'Arqueologia de Calafell (Calafell - Tarragona, 6 al 9 de març de 2007), Barcelona.

Sanz, C.; Velasco, J. (eds.) (2003): Pintia. Un oppidum en los confines orientales de la región vaccea. Investigaciones Arqueológicas Vacceas, Romanas y Visigodas (1999-2003). Catálogo de la Exposición, Universidad de Valladolid.

Sierra, J. M.; SAN Miguel, L. C. (1995): Las cañadas como medios de comunicación entre los asentamientos vacceos. En F. Burillo (coord.) 1995: 389-398.

Villaronga, L. (1978): Sobre la identificación de Segóbriga. Gaceta Numismática, 51: 13-17. 